Vimos que os procedimentos onde ocorre a inversão do contraditório podem comportar disciplina sistemática, com 0 que se evitaria a casuística, tão prejudicial a juízes e advogados, e tão pouco científica neste domínio

A verdade é que nossos processos especiais têm sido vítimas da improvisação de legisladores, com criação desordenada e cheia de lacunas.

Porque, por exemplo, não estender-se o procedimento monitório (lato sensu) do mandado de segurança contra o ato ilegal do particular?

Por que motivo os atos do administrador de entidades públicas, hospitais, educandários, por exemplo, podem ser suspensos pela liminar da segurança, e atos idênticos, igualmente lesivos, de administradores dessas mesmas entidades, quando privadas, escapam aos efeitos da salutar medida, em virtude da absoluta carência, entre nós, de remédio processual expedito e adequado.

Aqui ficam, pois, estas sugestões em prol da adoção, no novo Código, de modelos sistemáticos de procedimento monitório, de forma a eliminar-se, em proveito da celeridade dos juízos e perfeição e harmonia no emprego, até ampliado, do remédio, o abundante e estéril casuísmo vigorante entre nós.

Podemos justamente orgulhar-nos de nossas criações no que concerne ao direito processual-constitucional.

Urge, porém, quanto antes, que idêntico sentimento nos invada em relação ao direito processual, ele mesmo, de tal modo que a aunciada reforma concilie os ideais de justiça eficaz com procedimento célere, para que nossos isntrumentos de declaração e realização daquilo que é justo acompanhem, sem demora, os ventos de renovação e de progresso que sacodem, atualmente, este imenso e admirável País.

\section{A HIPOTECA NO DIREITO COMPARADO}

\section{Prof. Clovis V. Couto e Silva}

1. A hipoteca, atualmente, apresenta semelhanças não só nas legislações dentro dos sistemas de direito continental, como também entre estas e a da "common law". Em decorrência das necessidades sempre crescentes da economia moderna, surgem, em todos países, lesões ao princípio da acessoriedade da garantia real a um crédito, bem como a outro princípio da hipoteca tradicional, o da indivisibilidade. O princípio da acessoriedade excepciona-se em virtude de admitirem certos códigos e legislações as dívidas imobiliárias, as hipóteses pré-constituídas, não vinculadas a nenhuma relação creditícia que lhes sirva de suporte. Outras modificações ocorrem quanto à execução, pela possibilidade de ser efetivada de modo extra-judicial, com o que se evitam as demoras do processo de excussão hipotecária.

Dogmaticamente, a hipoteca insere-se no conceito mais geral dos negócios jurídicos de disposição. Nosso Código Civil não construiu com simetria a teoria das alienações e a da constituição de ônus ou gravames, quando se cuida de examinar a eficácia do registro de imóveis, ou sua constitutividade. O registro, em nosso direito, é constitutivo para as alienações e meramente elemento de eficácia quanto às garantias reais sobre imóveis. No direito brasileiro, a hipoteca existe "inter partes" antes ainda de ser levada à inscrição no registro imobiliário, quando então sua eficácia se estenderá a terceiros. Nossa jurisprudência corrigiu a anomalia, mas não deu à constitutividade do registro, em matéria hipotecária, todas consequências, pois não se tem admitido hipoteca sobre bem próprio. Por fim, a hipoteca se presta a um estudo de direito comparado porque através dele se verifica que a mobilização da riqueza imobiliária suscita em todos os sistemas instrumentos jurídicos semelhantes, ainda que não tenham, aparentemente, nenhum ponto de contato como sucede entre o nosso sistema hipotecário e o da "common law". 
$\S 1$ ò - A hipoteca medieval e a "mortgage" da "Common law".

2. No sistema romano e na maioria das legislações modernas não se conferiu a faculdade ao credor pignoratício, anticrético ou hipotecário de adquirir a propriedade do bem dado em garantia. Impede-se, assim, a aposição de clásulas comissórias. No direito medieval e na "common law", consagrou-se a possibilidade do credor hipotecário tornar-se titular do domínio se a dívida não fosse adimplida em seu vencimento. A hipoteca é "hipoteca de coisa". O desenvolvimento histórico da figura no direito medieval e na "common law" demonstra uma progressiva transformação da "hipoteca de coisa" em hipoteca sobre o valor do bem gravado.

A construção inicial da hipoteca, no direito medieval, era a de alienação em garantia, ou seja sob condiçăo resolutiva do adimplemento da dívida. ${ }^{1}$ Nessa época, como a posse do bem dado em garantia passava ao credor, não diferia a hipoteca do penhor. A alienação assumia, por vezes, a figura de venda com pacto de retrovenda com escopo de garantia de um empréstimo. Era possível realizar a alienação em garantia sob condição suspensiva do cumprimento da dívida. A vantagem, no caso, era do devedor que podia reter a posse e conseqüentemente usar e fruir a propriedade. Normalmente a hipoteca era de uso e fruição, podendo o credor perceber os frutos e rendimentos, o que não sucedia com o penhor. Facultava-se, na hipoteca, a ambos os figurantes do vínculo convencionar que os frutos e demais utilidades compensariam o uso do dinheiro dado em empréstimo, seja simplesmente para abater os juros hipótese em que poderia haver suspeita de usura - ou 0 principal. No direito franco, denominava-se a primeira possibilidade de "mortgage" e a segunda, de "vifgage".

Constituem ambas as formas - logo se percebe - modalidades de anticrese, ainda previstas em muitos códigos. A denominação "mortgage" é bastante exata para exprimir a idéia de que o bem gravado ficava "inerme" ou "morto" para o seu proprietário. Quando se convencionava que as utilidades do imóvel percebidas pelo credor compensariam o principal então dizia-se que o bem gravado era operante, estava "vivo" e trabalhava para o devedor, extinguindo progressivamente a dívida (vifgage). Esse primeiro conjunto

1. Otto von Gierke, Schuld und Haftung, pág. 26 e segs., ed. 1910 (1969) de normas, ou estatuto, tinha o "nomen juris" de "engagement". ${ }^{2}$

Era comum verificar-se que o direito do credor de adquirir o bem gravado quando o devedor não adimplia sua obrigação lesava a este, pois o imóvel, em regra, possuía valor superior ao crédito. Para evitar o dano, a hipoteca evoluia no sentido de possibilitar ao credor vender o bem gravado, no geral judicialmente, devendo devolver a quantia que excedesse ao crédito que se denominava de 'hyperocha'. Nessa fase, a hipoteca recaia sobre o valor do imóvel onerado e conferia a pretensão de vender judicialmente o bem, e, com isso solver a dívida. Essa transformação ocorreu porque em algumas cidades medievais a hipoteca deixara de ter a feição de anticrese, não conferindo ao credor a faculdade de fruir a substância do bem gravado, tendo o devedor a posse imediata e o credor o direito de excutir o bem hipotecado. Denominou-se, no direito franco, a esse estatuto de "obliga. tion".

Com todas essas modificações, surgiu a virtualidade de hipotecar-se mais de uma vez o imóvel, pois o credor não detinha a posse imediata e revelava-se o princípio das "parcelas de valor" da propriedade, de modo que, se o primeiro oravame não abrangesse a totalidade do valor do imóvel, podia o resíduo ser novamente onerado e assim até a exaustão. ${ }^{3}$

3. O direito hipotecário da "common law" tem suas raízes nos sistemas hipotecários medievais anteriores ao estatuto da "obligation" e foi introduzido para garantir transações com mercadores estrangeiros. A própria denominação "mortgage" revela sua origem."

No direito inglês, atualmente, ao cabo de uma longa evolução, a hipoteca abrange na sua estrutura tanto o direito do credor tornar-se proprietário ("hipoteca de coisa"), quanto o de vender o bem gravado judicialmente ou extra-judicialmente ("hipoteca de valor"). Mas não são as únicas faculdades que a "mortgage" confere ao credor ("mortgagee"), pois tem ainda o direito de tomar posse do imóvel gravado, para abater progressivamente a dívida que não foì solvida à data do adimplemento, seja quanto ao principal

2. H. Mitteis, Deutschee Privatrecht, pág 92, ed. 1950
3. H. Mitteis, Deutsches Privetrecht, página 92.

3. H. Mitteis, Deutsches Privetrecht, pagina 92
4. O termo "mortgage" segundo Littleton (cerca de 1370) poderia também significar O termo "mortgage" segundo Litteton (cerca de 1370) poderia também significar
que se o pagamento da divida não se efetivasse, a propriedade ficaria "morta"
para o devedor, l.é. ele a perderia para sempre. (Walsh, "On Mortgages", pág. para o devedor, te.e ele a perderia para sempre. (Walsh, "On Mortgages", pág.
4, N. Y., 1934). 
("vifgage"), seja quanto aos juros ("mortgage"), podendo, para isso, designar um terceiro para administrá-lo e compensar-se com os frutos.

Tão tradicional era o direito inglês, que no século XVII, a hipoteca se constituía através da convenção de transferência da propriedade plena ("fee simple") com a cláusula ou pacto de retransmissão ("reconveyance") ao devedor com o pagamento da dívida na data fixada.

Esse pacto conferia ao credor a garantia e um lucro com a utilização do imóvel e com o inadimplemento. A "Equity" poderia determinar ser esse direito exercitável até a época em que fosse declarada a preclusão judicial ("foreclosure") do aludido direito de remissão. Assim, o inadimplemento deixou de operar como uma condição, posto que a. consolidação definitiva da propriedade em mãos do credor dependia de uma decisão da "Equity", facultando-se, até esse montante, ao devedor o exercício do direito de remir. Modificação igualmente significativa para transformar a "mortgage" em mera garantia e não em fator de extorsão e lucro do credor, foi a possibilidade da "Equity", no processo de preclusão, verificar se o bem gravado tinha valor superior ao da dívida e, na hipótese afirmativa, determinar sua venda e atribuir ao credor a quantia necessária à solução da dívida e ao devedor o remanescente. ${ }^{5}$

O conjunto dessas medidas alterou fundamentalmente a estrutura da hipoteca de modo que o direito que tem 0 credor de tomar posse do bem gravado, por exemplo, tornou-se desinteressante em face da necessidade de pagar um aluguel ou arrendamento fixado judicialmente. Em razão disso, tornou-se comum a aposição dos contratos de hipoteca da cláusula de que o inadimplemento do devedor autorizaria ao credor vender aterceiros o bem gravado e ressarcir-se re suas despesas, devolvendo o restante ao devedor. A faculdade de vender extra-judicialmente o imóvel gravado tornou-se direito estatutário desde o Lord Cranworth's Act, em 1885.

A dificuldade maior para verter o direito inglês em termos de direito continental de tipo romanístico, está em que os conceitos e a estrutura de certas figuras não são iguais na "common law" e na "Equity", embora em princípio vigore a regra "Equity follows common law". Antes da grande reforma instituída pela "Law Property Act", em 1925, na "common law" o credor hipotecário tinha propriedade plena dos bens gravados e um direito à pose imediata;

3. Megarry - Wade, The Law of Real Property, pág. 842 e segs., ed. 1464. o devedor era apenas titular do direito de remição, que se exercita com o cumprimento da obrigação, direoto esse que se assemelha ao que decorre da nossa retrovenda.

A concepção da "Equity" é totalmente diversa e se aproxima ao estatuto da "Obligation" com uma construção típica dessa jurisdição especial. Considerou-se a princípio o devedor hipotecário como "cestui qui trust", dando-lhe em conseqüência a propriedade "beneficial owner" $€$, de modo que aparentemente o proprietário seria o credor, mas em realidade esta permanecia como devedor. Por fim, chegou-se a admitir que embora não tivesse o devedor o direito de remir antes do vencimento do mútuo, detinha ele na "Equity" a propriedade do bem, embora sujeita a um ônus, gravame, ou vínculo ("lien"). O credor hipotecário, por sua vez, é apenas titular de um direito real de garantia em soisa alheia, que se denomina no direito inglês de "incumbrance". A A concepção da "Equity", de que o devedor tem sua propriedade apenas onerada, se aproxima da noção atual que tem seu fundamento no estatuto medieval da "Obligation" e o termo "lien" revela bem essa procedência.

A "Law Property Act" (1925) adotou as concepções da "Equity" pois o devedor é proprietário pleno, tendo o credor um ônus ou gravame em garantia de uma dívida. E da natureza da hipoteca do direito inglês a possibilidade de preclusão do direito de remir o gravame, com a conseqüente integracão do bem gravado no patrimônio do credor e o direito de tomar posse do imóvel, no caso de não haver o devedor na data do vencimento da dívida prestado o principal ou os juros, com a finalidade de compensar-se do empréstimo realizado Esses remédios conflitam, de modo que iniciado o processo de preclusão não se pode pretender a posse do bem para abater progressivamente a dívida. Afora isso, existe a faculdade de vender o bem extraindo-lhe o valor, seja judicial, ou extra-judicialmente pelo próprio credor, ou por terceiro se houver sido convencionado.

Estabelecido o processo de preclusão do direito de remir tem 0 devedor, ou qualquer outra pessoa que possa sofrer prejuizo, o direito de requerer que o imóvel seja vendido judicialmente, com o que se evitam muitas situações iníquas. Para isso, basta verificar o que sucederia com os demais credores hipotecários se esses não pudessem objetar contra o desenvolvimento do processo de preclusão. Conferiu-se ao credor desde 1885 ("Lord Cransworth's Act") o direito es-

C. Walch, on Mortgages, página 12.
7. Megarry - Wade, The Law of Real Property, pág. 846. 
tatutário de vender o bem privadamente, para satisfazer-se com o seu valor. Discutiu-se, no direito inglês, qual a posição do credor, como titular do direito de vender privadamente, e a opinião predominante é a de que pú prodafiduciário do "power of sale". Entretanto, ainda que não detenha essa qualidade no pertinente ao poder de venda, ele è "trustee" dos procedimentos resultantes da venda ("proeeds of sale"), ao satisfazer o seu crédito ta venda ("propagar os demais credores hipotecários, todas as o dever volver o saldo, acaso existente, ao devedor, segundo uma ordem estabelecida na "Law Property Act". 8

A alienação efetivada pelo credor tem a natureza de uma venda forçada. Não está, por isso mesmo, obrigado a procurar quem dê melhor preço, ou estabelecer alguma forma de concorrência ou licitação privada como medida preliminar à alienação. Apesar de tudo, não pode vender com a intenção de prejudicar o devedor ou os demais interessados, nem adquirir o imóvel ainda que por interposta pessoa.

Verifica-se pelas faculdades contidas na estrutura da "mortgage" que ela não corresponde perfeitamente à hipoteca do direito continental, pois faculta - o que já não é comum - ao credor através da preclusão judicial tornar-se proprietário do bem gravado; permite-se ainda a venda extra-judicial do imóvel pelo credor, sem que se considere a este como fiduciário do devedor e proprietário, quanto ao "poder vender"; por fim admite-se como modalidade de execução, a transformação da nipoteca em anticrese, fruindo o credor as utilidades e compensando, por este meio, a dívida. Vemos que a hipoteca inglesa é também acessória a um crédito, embora tenha neste particular, sofrido importantes al-
terações.

Assim, a hipoteca de coisa futura não é permitida pela "commen law" que a tem como nula. Todavia, a "Equity", de longa data, a considera válida como contrato implícito de gravar o imóvel ainda inexistente, quando o devedor o adquirir. ${ }^{9}$ Lesão mais grave ao princípio da acessoridade, encontra-se quando o devedor vende a propriedade gravada, ou seja, a "Equity of redemption" a um terceiro; se este solver o débito adquire a seu favor a hipoteca.

Tem-se aí uma hipótese que fere frontalmente o aludido dogma da acessoridade, podendo o gravame ser cedido outrem, mantendo sua prioridade. Certamente, o mesmo não sucede quando o próprio devedor é o proprietário e sol-

8. Megarry - Wade, The Law of Real Property, página 866.
9. Walsh, on Mortgages, página 55 . ve, porque, neste caso, ele está adimplindo sua obrigação e, segundo o direito inglês, não teria sentido em manter a hipoteca em seu favor. Com essa solução, melhora-se o "status" econômico dos demais credores hipotecários. ${ }^{10}$

4. A "common law" americana, obviamente, guarda muita semelhança com o direito inglês, mas seu desenvolvimento não seguiu inteiramente a mesma orientação, em pontos fundamentais. Não se pode desconhecer que a legislação a respeito é estadual. Um aspecto relevante do direito americano em face do direito inglês reside na atitude de recusa em aceitar os princípios da "Equity" pelas antigas colônias ao se tornarem estados independentes, pois não tinham confiança nos poderes da Chancelaria, por lembrarem-se das faculdades conferidas aos "Royal Governors". Somente se reconheceu à "Equity", nos Estados Unidos, a categoria de um verdadeiro sistema jurídico, a partir da segunda década do século passado. ${ }^{11}$ A transposição para o direito americano do conceito de hipoteca segundo a "Equity", ocorreu algum ternpo antes, em 1809, num caso famoso, Jackson v. Willard, em que o "chief justice" Kent estabeleceu a natureza da "mortgage", traduzindo o conceito usual na "Equity": "the courts of law inclined to look upon a mortgage, not as a state in fee, but as mere security of debt". ${ }^{12}$

A hipotéca é, também lá, em princípio, estritamente acessória e a sua natureza é de mero vínculo, onus ou gravame, não dando lugar em princípio a que o credor possa exigir a posse do bem hipotecado, para fruir-lhe a substância. O devedor ("mortgagor") é proprietário do imóvel gravado a menos que se disponha de modo diverso.

A sua vez, considera-se a preclusão como forma que abrange todos os casos de extinção do direito de remição. Constitui-se em termo técnico bem mais geral do que no direito inglês, pois, naquele, incluem-se todas as formas de execução hipotecária, inclusive a venda particular pelo credor

Distingue-se a hipoteca americana da inglesa, porque naquela o direito de vender particularmente somente existe quando for conferido pelo devedor hipotecário ${ }^{13} \mathrm{e}$, nesta, esse poder se insere na sua estrutura independente de con-

10. Megarry - Wade, The Law of Real Property, página 806

Kurt Rudolph, Die Bindungen des Eigentums, página 31, ed. 1960

ortgage, página 22

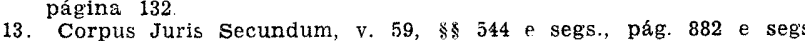


venção. Ao conferir o poder de vender, pode o devedor indicar quem o exercerá.

Se for beneficiário o próprio credor, entende-se que este detem uma posição bifronte, sendo em face do poder de venda um fiduciário, e um "cestui", ou beneficiário, com relação à extensão de seu direito no bem gravado. ${ }^{14}$ Discutem, porém, se seriam aplicáveis a essa venda particular as regras da venda forçada. As opiniões se dividem; mas se consideram o credor como fiduciário do poder de venda como sucede preponderantemente, deverão aplicar princípios diversos dos do direito inglês, no qual não se dá, neste particular, ao credor essa categoria. Por fim, a hipoteca americana acompanha a inglesa em suas lesões ao princípio da acessoriedade e, no pertinente ao crédito, admite a "hipoteca pelo valor máximo", ou "por importância não determinada", pois pode ser conferida para cobrir todo tipo de empréstimos, ou outros débitos, cujo montante ainda não se conhece, pelo período previsto na própria "mortgage", sendo assim aplicável também às contas correntes bancárias. 15

\section{$\$ 2^{9}-0$ sistema hipotecário do BGB.}

5. A hipoteca do direito moderno supõe, diversamente do penhor, que o devedor hipotecário permaneça na posse do bem gravado, extraindo os seus frutos e, no direito continental, segundo a tradição do direito romano, proibiram-se as cláusulas de comisso, mediante as quais podia o credor tornar-se proprietário por força do inadimplemento.

Em alguns sistemas, permitiu-se a emissão de cédulas hipotecárias, destinadas a circulação, e não totalmente acessórias a um crédito. Essas últimas não exercem apenas uma função de garantia, mas constituem-se em eficiente instrumento de capitalização do proprietário. No Código Civil Francês (arts. 2.144 e segs.), a hipoteca é estritamente acessória e a aplicação do Código Napoleônico, na Alemanha (Renânia), através do "rheinisches Civilgesetzbuch", até a entrada em vigor do BGB, causou danos profundos ao crédito imobiliário, fazendo necessário o aparecimento das primeiras cooperativas de crédito ("Raiffeisenkassen").

A situação tornou-se ainda mais grave porque naquele Código se permitia, em numerosos casos, hipoteca sobre todo o patrimônio. ${ }^{16}$

14. Corpus Juris Secundum, v. 59, \& 554, pág. 910.

106, $13 \mathrm{Sw}(1890)$ etc. A- Walsh, On Mortgages, Banking Co. v. Leonard $90 \mathrm{KY}$ 16. H. Mitteis. Deutsches Privatrecht, pág. 80 e segs.
O direito germânico atual distingue quatro tipos de garantias, a hipoteca de tráfico e em garantia, a dívida imobiliária e a divida imobiliária de renda, sendo que essa última tem escassa aplicação prática.

Distingue-se hipoteca e dívida imobiliária porque esta não tem, em princípio, nenhuma vinculação com alguma relação creditícia; não é acessória.

\section{Hipoteca de tráfico e hipoteca em garantia}

6. A acessoriedade da hipoteca em relação ao crédito constitui-se em axioma fundamental, por força do $\& 1.153$ do $B G B$, no qual se dispõe que "com a transferência do crédito, transmite-se a hipoteca ao novo credor"; e a alí nea II do mesmo § 1.153 dá ênfase à essa idéia, ao determinar que 0 "crédito não pode ser transferido sem a hipoteca, esta sem aquele". A afirmação de uma regra de tão estrita acessoriedade ou inseparabilidade do crédito e de sua garantia viria criar dificuldades ao tráfico jurídico. E a dificuldade aumentaria, na justificação dogmática, quando o princípio da acessoriedade fosse posto em confronto com o axioma da constitutividade de inscrição do gravame no registro e a fé pública dele resultante. A constitutividade do registro e a abstração do acordo de constituição do onus real dificultam a vinculação da garantia com qualquer realidade exterior ao albo imobiliário. Para harmonizar o princípio da acessoriedade com a natureza do sistema de registros adotou o BGB, como regra, a hipoteca de tráfico ("Verkehrshypothek") e não a em garantia. E. em conseqüência dessa posição, exarou o BGB, no $\S 1.138$, normas que definem a essência da hipoteca de tráfico e põem em harmonia a regra da acessoriedade com os demais axiomas que fundamentam os registros públicos, determinando que "os princípios dos $\$ \S 891$ até 899 vigoram para a hipoteca também em face dos créditos e das exceções que cabem ao proprietário, nos termos do $\$ 1.134$ ".

Esses parágrafos (891 a 899) definem precisamente a fé pública do registro e os procedimentos de retificacão e inscriçäo de objeção contra alguma inscrição feita anteriormente e a sua eficácia perante terceiros. Aplicando essas regras, conclui-se que se o devedor prestou a importância que ele devia ao credor, mas não cancelou a inscricão no registro próprio, e se o credor ou algum seu sucessor transferir o crédito e a hipoteca a terceiro, ter-se-á que a transferência do crédito é nula, pois a dívida já fora quitada, mas a da 
hipoteca vale e é eficaz. No caso, cabe ao titular da hipoteca somente a ação de execução do imóvel gravado e não a de cobrança de empréstimo. 17

A eficácia do registro de imóveis não "dominifica "a relação creditícia tornando-a oponível a terceiros. No sistema germânico, a publicidade diz respeito apenas ao ônus real inscrito e não ao crédito ao qual acedeu. As regras a respeito da extinção dos créditos não são atingidas pelo sistema registral, de modo que, solvida a dívida, não adquire o terceiro a posição de credor. Torna-se titular, contudo, da garantia real, porque esta virtude lhe confere o sistema dos registros públicos por força de sua constitutividade e de sua fé pública.

Em regra, a hipoteca é de tráfico, isto é, destinada a circular permitindo a aquisição pelo terceiro da garantia real, ainda que extinto o crédito e dando margem a que se afirme haver aí um afastamento do princípio da acessoriedade em favor da mobilização. Como a hipoteca de tráfico é destinada a circular emite-se, sobre ela, uma cédula hipotecária ( $\S 1.116$, alínea I) e o credor torna-se titular da hipoteca quando o devedor lhe transfere a cédula, podendo convencionar-se que o credor a receberá do próprio registro de imóveis, presumindo-se, entretanto se o credor estiver posse da cédula, que a recebeu por tradição do devedor ( $\S$ 1.117, alíneas I a III)

As hipotecas em garantia ("Sicherungshypothek") realizam, em toda a sua plenitude, o princípio da acessoriedade mas constituem exceção. ${ }^{18}$ Determina-se no $\delta 1.185$ que "a hipoteca pode ser feita de tal modo que o direito do credor hipotecário se determine ou exerça "somente em conformidade com a relação creditícia, não sendo permitido ao credor, para a prova de crédito, servir-se da inscricãa",

Mais importante, para esse tipo de hipoteca, do que as realidades do registro são as vicissitudes pelas quais pode passar a relação obrigacional; o axioma da constitutividade do registro e a fé pública perante terceiros cedem a sua posição ao princípio da acessoriedade, de tal modo que realizada a cessão do crédito hipotecário, o adquirente somente terá o direito de cobrá-lo ou executar a hipoteca,

17. Baur, Sachenrecht, \& 36, pág. 289, ed. 1969.
13. A denominacão hipoteca de tráfico e hipoteca

uma yez que equelas ta de trífico e hipoteca em garantia é em parte equivoca,

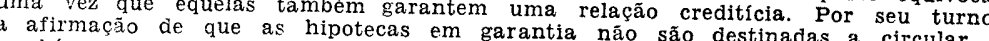

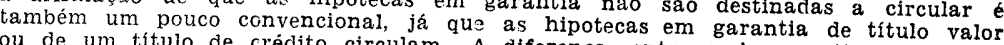
teca está antes na efiććcia do registro de imẹa, entre ambos os tipos de hipode suas modificaçōes, sobre a a relacia crediticia, qua náo se aplica, do mesmo
modo, em ambas as formas de hipoteca. de hipoteca. quando aquele ainda não houver sido solvido, pouco importando o que constar no registro. Extinto o crédito, desaparece a hipoteca, sem que tenha havido ainda o cancelamento da inscrição. ${ }^{19}$ A hipoteca em garantia necessita estar expressamente assim designada no registro; caso contrário, a hipoteca será de tráfico. ${ }^{20}$ Exclui-se nesse tipo de gravame, a emissão de cédula hipotecária. ${ }^{21}$

O discrime entre os dois tipos de hipoteca, de tráfico e em garantia, resulta, em última análise, da eficácia da inscrição no registro imobiliário sobre os cessionários. A hipoteca em garantia libera-se da constitutividade do aludido registro, para acompanhar, em todas as suas modificações, o crédito por ela garantido, independentemente do que constar nos livros fundiários, como sucedia com as hipotecas no "direito comum" que eram estritamente acessórias. Decorre daí que lhe não são aplicáveis as regras que tem o seu suporte no sistema imobiliário germânico. Não se pense, entretanto, que o direito germânico, em matéria hipotecária tenha aberto exceções que subverteriam totalmente a teoria dos negócios jurídicos dispositivos, que são abstratos. O acordo de constituição da hipoteca em garantia não deixou de ser abstrato, todavia o registro, quanto às demais alterações da reiação creditícia, transferências, solução do débito etc., perdeu a virtude de ser constitutivo; o fundamental não é o que ele contém, e sim o crédito, o qual em razão da regra do $\$ 1.184$, determina o regime jurídico de ônus real. ${ }^{22}$

Para se trazer luz ao específico do problema, basta supor que alguém dê em hipoteca, seja de tráfico ou em garantia, um imóvel que esteja registrado em seu nome, mas cujo negócio jurídico obrigacional subjacente contenha algum vício que o torne nulo. Como o acordo de constituição de ônus é abstrato, sem nenhuma vinculação com o negócio antecedente, a hipoteca constituída é válida e eficaz e o credor é em verdade titular da garantia real. Quanto à constituição do ônus, nenhuma diferença existe de tratamento jurídico, neste particular. Imagine-se, também, que o crédito assegurado pela hipoteca já tenha sido solvido, no todo

19. Baur, Sachenrecht, \& 36 , página 290

20. 3.184 , alínea II

Sxplicacáo diversa é a de Eichler IInstitucionen des Sachenrechts. II, 2, pás. 484, ed. 1960$)$ e tambèm a de Palandt - Hoche, (Kommentar zum BGB, 1.184 réditos, quando se tratar de hipoteca de tráfico; na em garantia os aludidos Nao nos Darece exata essa opinião, porque se fossem aplicáveis aos créditos o
aludidos \&s 891 e segs, ter-se-ia aldatos 891 e segs., ter-se-ia, que na hipoteca
crédito jà solvido o adquiriria, o que não è certo. 
ou em parte, e não se tenha feito a retificação do registro imobiliário. Na hipoteca em garantia, nenhum efeito tem a inexistência de retificação; mas o oposto sucede com as de tráfico, no pertinente à garantia real. Na hipoteca de tráfico, se não houve retificação, não é oponível a terceiros a modificação no conteúdo da relação de direito rear diferenças, portanto, não se manifestam no início, quanto à constituição do gravame; elas ocorrem posteriormente.

7. As hipotecas em garantia podem ser "pelo valor máximo" ("Maximmalhypothek; Nóchstbetragshypothek"); ou em"em garantia de títulos de crédito" ("Wertpapierhipothek"); ou simplesmente em garantia, como sucede com as hipotecas do direito francês, português ou italiano.

As hipotecas "pelo valor máximo" supõem a indeterminação prévia do montante da dívida a ser garantida e do momento em que ele se determinará. Vinculam-se a créditos futuros, tais como os que podem nascer de uma conta corrente bancária, ou de relações duradouras, cujo saldo não possa ainda ser determinado. Até o momento em que a pretensão do credor se objetivar a hipoteca será pelo va lor máximo e depois por quantia fixa. A hipoteca não está sob condição; é hipoteca pura que grava desde logo o bem pelo valor máximo em que foi inscrita, ${ }^{23} \mathrm{de}$ modo que não se pode pensar seja ela, no período interimístico, que não momento em que a pretensão quanto ao seu exato valor dívida imor determinada Eichler ${ }^{24}$ ou dívida inobiliária, como sugere da, como quer Baur. ${ }^{25}$.

A particularidade dessa figura está em que ela supõe, como exigência de direito material, que se inscreva no registro o valor máximo da garantia, de tal modo que constar o valor não pode ser realizada a inscrição. ${ }^{26}$

As hipotecas em garantia de títulos de crédito representam uma excelente adaptação dos princípios hipotecários aos do direito cambiário.

Não se extrai, nessa hipoteca, uma cédula que a corporifique, porque isso é vedado a todas as hipotecas em garantia. Como os processos de circulação, de substituição dos credores hipotecários, são diversos, gistral e o direito cambiário, resolveu-se a dificuldade, no

23. Staudinger - Kober, Mommentar zum BGB, III, \$1.190, pág. 950 7.a e 8.a ediçăo.
24. Eichler, Institutionen, II, 2, pág. 490.

26. Seergel - Baur, Kommentar zurn BBG, t. 4, \& 1.190, pág. 729, ed. 1968. caso, aplicando-se os princípios de transferência do direito cambiário, ou seja, por acordo de transmissão, seguido de tradição do título, ou por endosso.

Cuida-se na realidade de um título de crédito ao qual acedeu uma hipoteca, inscrita no registro imobiliário, circulando aquele, com sua garantia, segundo as regras do direito cambiário. Aqui, convém esclarecer que a hipoteca depende do crédito, já que predomina o princípio da acessoriedade. Por ser um título de crédito, circula com as regras que lhe são próprias, não transmudando sua natureza o fato da relação creditícia estar garantida por uma hipoteca.

Como esses títulos de crédito são abstratos, o terceiro o adquirirá independentemente do negócio subjacente. E assim os vícios da relação creditícia antecedente não são oponíveis aos adquirentes de boa fé. Em tais termos, desde que o terceiro adquira o crédito, sem que o direito leve em consideração os vícios que possa conter a relação creditícia se torna titular da garantia real. À sua vez, como é o crédito quem determina o regime jurídico, pode suceder uma falta de coincidência entre o credor inscrito e o real, mas o litígio se resolve segundo o princípio de que o credor é somente o endossatário, ou detentor, se a hipoteca estiver garantindo um título ao portador. Por fim, tem a hipoteca em garantia de título de crédito significação jurídica e econômica semelhante à da hipoteca de tráfico. A diferença maior está na acessoriedade das hipotecas em garantia, mas esta se torna mínima em virtude da abstração dos títulos de crédito. Apesar disso, há tratamento jurídico diverso quanto à hipoteca em garantia de título de crédito, o qual pode ressaltar do fato de ser incapaz o emitente, ou de ter sido o título posto em circulação contra a sua vontade. ${ }^{27}$

8. Nas hipotecas acessórias a títulos ao portador, a letras de câmbio, ou a outros títulos que podem ser transferidos mediante endosso, ${ }^{28}$ pode-se designar um representante ("Grundbuchvertreter") legitimado fiduciariamente a representar o credor no desenvolvimento das relações hipotecárias, inclusive na execução. ${ }^{29}$

O acordo que designa o representante deve ser inscrito no registro imobiliário para que produza efeitos. No particular adotou o BGB, o princípio dispositivo, pois depende a inscrição dos interessados, mas é inegável que a posição 27. H. Westermann, Lehrbuch des sacheurechts, \& 113, pág. 559, ed. 1960. 28. 1.189 
do representante é fiduciária não só do credor como também do devedor ${ }^{30}$ embora haja divisão na doutrina, pois muitos o consideram simplesmente representante que age

A tendência no direito germânico é a de estender, para efeitos de segurança creditícia, a figura do fiduciário a ou tras hipóteses $\epsilon$ demonstra assim a necessidade de inserção de terceiras pessoas na relação obrigacional, com a finalidade de assegurar a execução das hipotecas e penhores, como se verifica no direito americano, ${ }^{32}$ sendo para isso de maior valor o princípio contido no $\$ 1.189$ do BGB. Certo é que além dos casos previstos no $\$ 1.189$ não se permite a inserçäo de um terceiro como fiduciário, por ser na hipoteca figurante essencial o credor e não se pode constituí-la com um credor aparente, fiduciário do credor real. A dívida imobiliária, por não exigir nenhuma relação subjacente de crédito, pode servir à aplicação da "fiducia", conforme sustenta Siebert, porque o legitimado fiduciariamente receberia o título da dívida imobiliária no interesse do credor ${ }^{33}$ No direito germânico, chega-se a esse resultado através do contrato ou estipulação em favor de terceiros ${ }^{34}$

\section{A dívida imobiliária}

9. Como elemento fundamental do crédito real está a dívida imobiliária ("Grundschuld"), ou a hipoteca pré-constituída. A denominação dívida imobiliária parece ser melhor do que a de hipoteca pré-constituída, termo utilizado em alguns sistemas jurídicos modernos, porque este pode revelar, implicitamente, a acessoriedade, maior ou menor, à uma relação cređitícia. A nota característica da dívida imobiliária é o fato de, em regra, ser isolada ("isolierte Grundschuld"), ou seja, totalmente desvinculada de um crédito, pelo menos no momento de sua constituição.

Para dar ênfase a esse aspecto de sua estrutura, há quem afirme ser a hipoteca "causal", pois se relaciona a um crédito e a dívida imobiliária "abstrata", tanto vale dizer, uma vinculação real autônoma. A ela são aplicáveis no geral os princípios que regem a hipoteca, salvo aqueles que não se harmonizam com o elemento básico de sua estrutura,

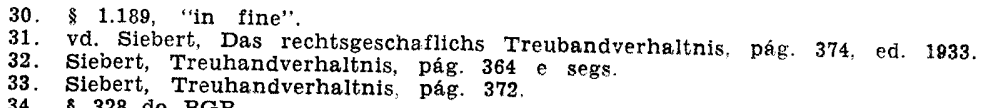

a circunstância de não pressupor uma relação creditícia que lhe sirva de suporte. ${ }^{35}$

A hipoteca subordina-se em seu nascimento a um débito e a sua finalidade principal consiste em satisfazer ao credor, na hipótese de não se ter realizado o adimplemento. A dívida imobiliária disso independe e pode ser extraída pelo proprietário em seu favor e somente depois vir a ser dada em garantia. A vantagem para o credor é evidente pois ele não necessita preocupar-se em saber se a relação creditícia subjacente existia ou não, podendo sempre executar o imóvel gravado. A composição dos interesses, na hipótese de não haver causa, far-se-á do mesmo modo que nas promessas abstratas, através do instituto do enriquecimento injustificado. ${ }^{36}$

Como pura responsabilidade real, a dívida imobiliária corresponde ao "Gült" do direito suíç, ${ }^{37}$ por meio do qual se põe um crédito como "ônus imobiliário", produzindo o efeito de desfazer a relação creditícia subjacente por força de uma novação "ex lege". ${ }^{38}$ A faculdade de extrair uma dívida imobiliária é muito importante também para o devedor porque, ao constituí-la por ato unilateral de inscrição no registro, poderá obter o gravame em primeiro grau. A hipoteca que venha a ser feita posteriormente será de segundo grau.

Essa possibilidade dá nova significação à figura dos pactos de reserva prelatícia, ou simplesmente de reserva de grau ("Rangvorbehalt"), admitidos pelo direito germâni$\mathrm{Co}^{39}$ e que têm grande importância para todo o sistema creditício, pois certas instituições somente concedem empréstimos com a constituição de gravames de primeiro grau.

A reserva de grau supõe acordo entre devedor e credor, de modo que este confere àquele a faculdade de registrar outro ônus real posteriormente, mas com prioridade de eficácia. Sendo possível ao proprietário extrair em seu favor uma dívida imobiliária, por negócio jurídico unilateral, só com essa providência, sem necessidade de nenhum acordo, Gle deterá a aludida preferência, pois o direito real em seu favor foi inscrito anteriormente. $O$ sistema creditício germânico opera com gravames de primeiro, segundo e até mesmo terceiro grau. Os bancos e as caixas ou associações

35. $\$ 1.192$ do BGB.

36. Staudinger - Kober, Kommentar. III. \& 1.191, pág. 966; Eichler, Institutionen

37. arts. 847 e segs. do ZGB.

38. vv. Eichler, Institutionen, II, 2, pág. 503, nota 2.
39. I 881 do BGB. 
de poupança concedem empréstimos com garantia hipotecária de primeiro grau. As entidades de direito público financiam mediante gravames de segundo ou terceiro grau, percebendo juros maiores correspondentes ao risco também maior. ${ }^{40}$

Utilizam-se nesses negócios creditícios hipotecas pelo restante do preço (alienação e hipoteca pelo saldo), hipotecas de amortização, por meio de pagamentos fracionados, ou através da organização de um fundo constituído pelos pagamentos do mutuário, para final compensação. A dívida imobiliária é direito real em coisa própria e uma lesão ao velho princípio "nemo res sua servit". A admissão de direitos reais sobre bens próprios permite que o pagamento, realizado pelo proprietário que seja ao mesmo tempo devedor pessoal, extinga a relação creditícia, mas não a hipoteca, o que suporia retificação do registro. Nesse caso, o proprietário torna-se detentor de uma "hipoteca sobre imóvel de sua propriedade", ou seja de uma dívida imobiliária. ${ }^{41}$ Se o proprietário for um terceiro, a solução do débito acarretará a transmissão em seu favor do direito creditício que cabia ao credor contra o devedor, e a constituição em seu benefício de uma dívida imobiliária. 42

O cireito hipotecário germânico dá ênfase à posição do credor e à dos terceiros, o que se manifesta na adoção, como regra, da hipoteca de tráfico, e na possibilidade de extrair-se uma dívida imobiliária, e também ao devedor, pela facilidade em constituir direitos reais de garantia. A figura do representante inscrito no albo imobiliário ("Grundbuchvertreter") torna mais segura a circulação das hipotecas em garantia de títulos de crédito, pois o devedor sabe perante quem deve operar-se a solução da dívida. O instituto da reserva de grau hipotecário serve muito bem aos interesses do devedor, dando-lhes maiores virtualidades na obtenção de empréstimos. Há, assim, uma certa ambivalência no direito hipotecário germânico: os institutos que protegem ao credor dão também segurança ao devedor.

\section{§ 39: A Hipoteca no Direito Brasileiro}

10. A hipoteca nos sistemas romanísticos, de que são exemplo o Código Civil Francês (arts. 2.144 e segs.), o Português de 1967 (arts. 686 e segs.) e o Italiano (Código Civil,

40. H. Westermann, Sacehnrecht, \& 91, II, página 445.

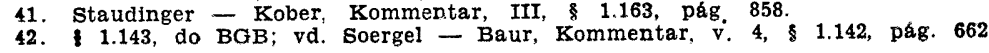

arts 2.808 e segs.) é estritamente acessória. No direito brasileiro, há certa dúvida a respeito sustentando Pontes de Miranda, 43 que nossa hipoteca se assemelharia à hipoteca de tráfico de direito germânico, embora não fosse emitida mediante cédula, o que lá se faculta excepcionalmente. A maioria dos autores têm a hipoteca como acessória, transmitindo, de alguma forma, como elemento interpretativo de nessas disposiç̃es, o direito francês e o italiano. A fundamentação de Pontes de Miranda tem suas raízes no disposto no artigo 850 do Código Civil Brasileiro, que faz depender a extinção da hipoteca do cancelamento do registro. Em matéria registral, há em nosso direito a particularidade de que a hipoteca antes da inscrição existe "inter partes", 44 de modo que o registro é mero elemento de eficácia, não tendo o efeito constitutivo que lhe atribuem, por exemplo, o direito germânico e suíço. Guardando simetria com a constituição do gravame, a extinção da hipoteca realiza-se entre os figurantes, entre outras hipóteses, pelo desaparecimento da obrigação principal, ${ }^{45}$ ainda que só comece a ter efeitos perante terceiros depois de averbada no respectivo registro, $4 \mathrm{e}$ embora seja diverso o entendimento da jurisprudência.

A existência da hipoteca "inter partes", antes da inscrição no registro, é princípio que não se harmoniza com o nosso sistema em matéria de alienações, posto que a propriedade somente se adquire com a transcrição ${ }^{47}$ e não se admite como sucede no direito francês ${ }^{48}$ e italiano ${ }^{49}$ a transferência para o adquirente do bem alienado antes da realização daquele ato.

Nessa parte, deve-se corrigir o texto porque os negócios jurídicos de disposição sobre imóveis, sejam translativos ou constitutivos de gravames, devem ter o mesmo regime jurídico. No particular, nosso Código Civil normou com desarmonia dos negócios dispositivos, seguindo nas alienaç̃es as regras do $B G B$ e, na hipoteca, as do Código Civil francês. Todavia, neste último Código há simetria entre as disposições, pois a compra e venda transmite "inter partes" a propriedade, sendo o registro mero elemento de eficácia perante terceiros. Não se pode, entretanto, adotar na disciplina, que deve ser unitária, dos negócios dispositivos regras coli-

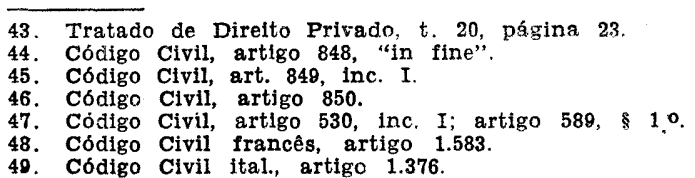


dentes entre si, considerando como uma das exceçóes à regra exposta no art. 676 do Código Civil a constituição das hipotecas negociais. ${ }^{50}$

O alcance que Pontes de Miranda dá ao artigo 850 é lógica e sistemática dentro das premissas de seu raciocínio, de que os acordos de transmissão de propriedade e os de constituiçăo de ônus sobre imóveis sejam abstratos e a eficácia do registro imobiliário "juris et de jure". Acolhendo em seu monumental Tratado de Direito Privado, em toda a sua extensão, o princípio da fé pública do registro, o artigo 850 passa a ter outra significação que não possuiria se os negócios dispositivos fossem causais, ou se a aludida fé pública, ao invés de absoluta, se constituísse em algo meramente relativo, de modo que a boa fé do terceiro adquirente não tivesse a virtude de lhe tornar indisputável a aquisição. Ocorre que em nosso direito a alienação foi considerada causal, não desligada dos negócios antecedentes, e a presunção de pertencer o direito real à pessoa em cujo nome se transcreveu, ou inscreveu, ${ }^{51}$ não é absoluta, nem essa presunção foi modificada pelo D. 4.857, de 9 de novembro de 1939, que estabeleceu o "Regulamento dos Registros Públicos", ou pelo DL. 1.000 , de 21 de outubro de 1969, que "consolidou e atualizou o aludido Regulamento". A jurisprudência tem como constitutivo o registro não apenas para as alienações, como também para a constituição de ônus, realizando desta forma uma obra de harmonização sistemática, embora esse não seja o sistema exposto nas disposições do nosso Código Civil.

Duas interpretações são assim possíveis para o artigo 850 do Código Civil Brasileiro: a) a transferência do crédito hipotecário a terceiro de boa fé, depois de solvida a dívida, preclui o direito de averbar a quitação, ou de cancelar a inscrição do gravame; b) a cessão a terceiros de boa fé não gera a decadência do direito formativo extintivo, de cancelamento da inscrição.

A solução a) assemelharia a hipoteca brasileira à hipoteca de tráfico do direito germânico; a outra, b), faria com que nossa hipoteca fosse igual à do direito comum, com certo temperamento porque a extinção não seria imediata, com a simples solução da dívida, mas dependeria da averbação, sendo entretanto hipoteca em garantia, isto é, acessória. 50. Certas disposiçōes, no direito de família, constituem em multos códigos, inclusive
no BGB, excecoes à regra da constitutividade do registro, como sucede quando
se opta por algum regime de bens, porque, no caso, o aludido registro é mero

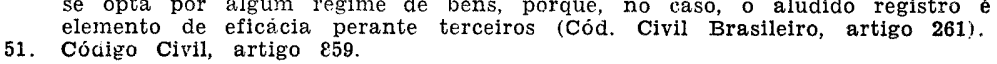

Pela redação do artigo 850 do Código Civil, "a extinção da hipoteca só começa a ter efeitos contra terceiros depois de averbada no respectivo registro", diversa aliás do artigo 848, pertinente à constituição tem-se que a solução do nosso direito é a da letra b), sendo a hipoteca meramente acessória.

\section{I o princípio da Acessoriedade}

11. A acessoriedade da hipoteca significa que a relação creditícia comanda e determina o regime jurídico da garantia de direito real. Mais do que isso, tem o sentido de que a garantia se refere sempre a um crédito. Particularidade interessante em nosso direito é a de que o ônus real constituído sobre bem de propriedade alheia, "a non domino" pertence, existe e vale, sendo apenas ineficaz, apesar da redação do artigo 756, \& único do Código Civil ser equívoca, porque alude à revalidação da hipoteca, quando quem a deu tornar-se posteriormente proprietário. Nosso Código Civil não normou as hipotecas pelo valor máximo, ou de importância não determinada, mas a praxe tem admitido o registro de tais hipotecas, exigindo-se, entretanto, um regramento dessa figura.

Discute-se no direito brasileiro a possibilidade de que o proprietário possa constituir sobre imóvel que lhe pertença uma hipoteca em seu favor. Pela afirmativa, manifestou-se Pontes de Miranda. ${ }^{52}$ A maioria dos autores nacionais, passou desapercebido esse problema, preocupados quase exclusivamente em explicar o direito hipotecário à luz do princípio de acessoriedade. À sua vez, a própria jurisprudência não deu maior relêvo ao princípio da constitutividade do registro e às consequências que dele haviam de derivar. É implícita assim a resposta negativa à possibilidade de constituição de ônus sobre bem próprio. O problema maior está em saber se quando o proprietário, devedor pessoal ou terceiro adquirente, solve a divída, adquire em seu favor a hipoteca, ou ela se extingue. O princípio da constitutividade do registro levaria à conclusão de que enquanto não cancelada a inscricão o gravame perduraria em favor do proprietário, se este fosse também devedor pessoal; se, no caso, ele fosse terceiro que deu sua propriedade em garantia de dívida alheia, terse-ia subrogação do crédito contra o devedor e aquisição de hipoteca soīre bem próprio, solução essa idêntica a do direito germânico, em que se deram todas as conseqüências ao

$\overline{52 .}$ Tratado de Direito Privado, v. 20, pág. 323 e segs. 
príncípio da constitutividade. A primeira dúvida está na possibilidade de existir a figura da hipoteca pré-constituída, como pré-forma da dívida imobiliária, ou mesmo como dívida imobiliária. A vantagem de tal sistema seria o de poder constituir um gravame real antes de se ter um credor e também a faculdade de reservar pela só vontade do proprietário uma melhor posição dentro do registro imobiliário. Para admissão dessa figura haveria necessidade de norma expressa, pois representa profunda lesão ao princípio da acessoriedade e embora a jurisprudência tenha considerado o registro como constitutivo, não consta que tenha admitido a extração de uma hipoteca sem que houvesse uma relação de crédito, servindo de suporte, sobretudo por força do artigo 755 do Código Civil que impõe, como elemento estrutural, a aludida dependência. ${ }^{53}$

12. Problemática das mais importantes é a das cédulas hipotecárias instituídas pelos DL. 70, de 21 de novembro de 1966, DL. 167, de 14 de fevereiro de 1967, e DL. 413, de 9 de janeiro de 1969. Por meio desses Decretos-leis criaram-se cédulas hipotecárias, destinadas a atender ao financiamento de construções pelo Banco Nacional de Habitação (DL. 70), da agricultura (DL. 167) e indústria (DL. 413).

O DL. 70 instituiu a cédula hipotecária para "hipotecas inscritas no Registro de Imóveis, como instrumento hábil para a representação dos aludidos créditos imobiliários". ${ }^{54}$ Podem recair sobre primeiras e segundas hipotecas ${ }^{55}$ e são emitidas pelo credor hipotecário, preenchidos certos requisitos, mas somente podem ser lançadas em circulação depois de averbadas à margem da inscrição da hipoteca a que disser respeito ${ }^{58}$ e depois de autenticadas pelo oficial do Registro Geral de Imóveis competente, com todas as indicações. ${ }^{57} \mathrm{~A}$ cédula é sempre nominativa, podendo ser transferida por meio de endosso nominal, lançado no verso ${ }^{58}$, de modo que a hipoteca passa a fazer parte integrante do título, acompanhando nos endossos subsequentes, subrogando-se o endossatário em todos os direitos creditícios. ${ }^{59}$ A cédula hipotecária instituída pelo DL. 70 é cédula hipotecária em garan tia, que se submete aos princípios da cessão de crédito por 53. Cód. Civil, art. 755: "Nas dividas garantidas por penhor, anticrese ou hipoteca,
a colsa dada em garantia fica sujeita por vínculo real ao cumprimento da
obrigacăo".

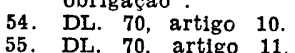

56. DL. 70, artigo 13 .

57. DL. 70, artigo 13,8 único

58. DL. 70, arttgo 16.8 s.
59.

116 força do disposto no artigo 16 do referido DL., embora haja no pertinente à forma de transferência alguns princípios de direito cambiário, tais os referentes ao endôsso. ${ }^{60} \mathrm{Na}$ cessão de crédito a título oneroso, o cedente é responsável pela existência do crédito, ${ }^{61}$ mas não o é pela solvência do devedor. ${ }^{c 2}$ A eficácia da cessão de crédito perante o devedor supõe que esse tenha sido notificado. ${ }^{33}$

No artigo 17 do DL. 70 exara-se a regra de que na emissão, ou no endôsso da cédula hipotecária, "o emitente e o endossante permanecem solidariamente responsáveis pela boa liquidação do crédito, a menos que avisem o devedor e o segurador, quando houver, de cada emissão ou endôsso até trinta dias após a sua realização por carta enviada mediante recibo, pelo Registro de Títulos e Documentos, ou ainda, por meio de notificação judicial..."

Essa regra não modificou o princípio de que a transferência da cédula se constitui em cessão "pro soluto", pois quando o artigo 17 do DL. 70 alude "a boa liquidação" se refere à circunstância de que não avisado o devedor da emissão ou do endôsso eles assumem solidariamente o risco de não se fazer o pagamento ao verdadeiro credor..$^{64}$

A entrega da cédula quitada ao devedor prova a extinção da hipoteca, independentemente do cancelamento da inscrição ${ }^{65}$ não havendo impedimento que esta prova se faça por outros meios. Se permanecer em circulação, porque não lhe quis devolver o emitente ou endossante são eles responsáveis perante terceiros adquirentes. ${ }^{.6}$

$\mathrm{O}$ § único do artigo 18 do DL. 70 abre uma problemática de interpretação de grande alcance. No caso de se haver solvido o débito e ter, inobstante isso, permanecido em circulacão a cédula, como se resolverá o conflito? Se na cédula hipotecária houvessem sido adotados os princípios do direito cambiário quanto ao fundo, então o terceiro adquirente de boa fé seria credor em virtude da abstração do título e, em consequência, titular da hipoteca, pois essa faz parte da cédula, acompanhando-a nos endossos. Por serem aplicáveis os princípios da cessão do crédito e sendo esta considerada entre nós, negócio jurídico dispositivo causal, tem-se que o terceiro não adquire o crédito, nem a hipoteca, mas deve ser indenizado.

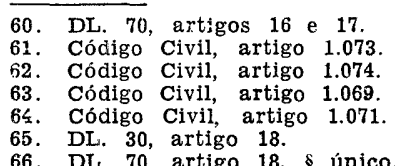

64. Código Civil artigo 1.069 .

65. DL. 30 , artigo 18 . \& unico
66. DL. 70 , artigo 18 , un 
A cédula hipotecária do DL. 70 distingue-se da hipoteca de tráfico do direito germânico, porque, nesta, não cancelado o registro, o terceiro adquire a garantia real (e não o crédito) e também da hipoteca em garantia de um título de crédito, porque a ele são aplicáveis os princípios do direito cambiário, quanto ao fundo, e não somente no que toca à forma de transferência.

13. Regime jurídico diverso é o das cédulas de crédito rural (DL. 167) e industrial (DL. 413). São promessas de pagamento abstratas, no pertinente aos créditos que corporificam. 67

A cédula de crédito rural terá a denominacão de cédula rural hipotecária, quando preencher os requisitos do art. 20, DL. 167, entre os quais está a descrição do imóvel hipotecado. A terminologia do DL. 413 é equívoca ao afirmar, em seu artigo $9^{\circ}$, que "a cédula de crédito industrial é promessa de pagamento em dinheiro com garantia real cedularmente constituída". Em verdade, não se extraem duas cédulas como a aludida disposição dá a entender, a de crédito industrial e a hipoteca cedular, ${ }^{\mathrm{cs}}$ garantindo esta àquela. O processo é totalmente diverso pois a cédula é uma só e tem a particularidade de constar em seu corpo, ${ }^{c} 9$ ou mesmo fora dele, em documento separado, ${ }^{70}$ ou até mesmo pela anexação dos títulos de propriedade à cédula de crédito industrial, $^{71}$ a descrição do imóvel, com suas confrontações, dimensões, benfeitorias, título e data da aquisição, etc.

A eficácia perante terceiros começa da data da inscrição da cédula de crédito rural ${ }^{72}$ e da cédula de crédito industrial ${ }^{73}$ no Cartório de Registro de Imóveis, devendo ser averbados os endossos posteriores à inscrição, avisos, aditivos, etc., e qualquer ato que promova alteração na garantia e condições pactuadas. ${ }^{74}$ Essas averbações são necessárias, para que as modificações no crédito ou na hipoteca tenham eficácia perante terceiros, pois de outro modo seus efeitos se reduzem aos contratantes. ${ }^{25}$

Por força dos artigos 24 do DL. 167 e 26 do DL. 413, aplicam-se à hipoteca cedular os princípios da legislação

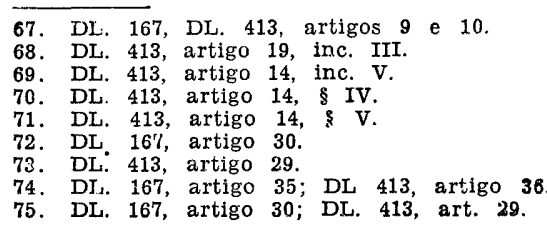

ordinária a respeito, desde que não colidam com preceitos de ambos os Decretos-leis.

Convém indagar, para descrever a estrutura da cédula de crédito industrial e da cédula de crédito rural garantidas por hipotecas, se lhes são aplicáveis as regras sobre a extinção da hipoteca comum, ${ }^{70}$ ou se os Decretos-leis 167 e 413 conferiram ao terceiro de boa-fé uma posição de inatacabilidade por qualquer outro interessado na relação obrigacional, ou real. Dever-se-ia questionar se a hipoteca inserida numa daquelas cédulas, após a circulação, daria ao terceiro adquirente a titularidade da garantia real, na hipótese em que quem a houvesse dado não fosse proprietário. Se a resposta pendesse para a afirmativa, estaria vigorando para estas cédulas o sistema de abstração dos negócios dispositivos, ou da causalidade, em que se deu proteção ao terceiro de boa-fé. Todavia, protegem-se os terceiros de boa fé, adquirentes da cédula hipotecária rural ou da cédula hipotecária industrial, por força dos artigos 30 e 35 do DL. 167 e artigos 29 e $3^{6}$ do DL. 413 , apenas quanto aos endossos posteriores à inscrição da cédula, as menções adicionais, aditivos e qualquer outro ato que promova alteração nas garantias e condicões pactuadas. Não se tem, em consequência, o sistema da aquisição da garantia real pelo terceiro, quando não for titular do domínio quem deu o imóvel em segurança das aludidas cédulas. Aplicam-se, neste particular, as regras dos negócios jurídicos dispositivos, os quais, entre nós são causais, por força de reiterada jurisprudência. Todavia, as modificações posteriores à inscrição da cédula, tanto na relacão creditícia, quanto no gravame real, que não tenham sido averbadas, não são oponíveis a terceiros. Tem essas cédulas a característica de não acompanharem o princípio da acessoriedade em toda sua extentão, pois mais importantes que as vicissitudes da relação creditícia são, perante terceiros, as averbações dessas alterações no Registro Imobiliário, em livro próprio, denominado, respæctivamente, de "Registro de Cédulas de Crédito Rural" 77 e "Registro de Cédulas de Crédito Industrial". 78

A cédula de crédito rural e a cédula de crédito industrial assemelham-se quanto ao tratamento jurídico, as hipotecas de tráfico do direito alemão, nas quais mais importantes que as modificações da garantia real são as alterações no registro imobiliário, o que fere o dogma da acessoriedade.

\section{Código Civil, artigo 850.}

$\begin{array}{ll}77 . & \text { DL. } 167, \text { artigo } 31 . \\ \text { 78. DL. } 413, \text { artigo } 31 .\end{array}$ 
Há diferenças específicas, não só quanto à constituição ou emissão, mas também quanto ao alcance da presuncão do registro; no direito germânico se restringe à garantia real, tanto que adimplido o crédito e não retificado o registro, o terceiro adquirente não tem ação obrigacional (o crédito está extinto) e sim a excussão real da garantia. Em nosso direito, ainda que solvido o crédito e não averbado o adimplemento, torna-se o terceiro titular da relação creditícia e real. Salva-se, assim, de alguma forma, o princípio da acessoriedade.

14. A cédula hipotecária no direito brasileiro ficou restrita a operações com instituições financeiras, ${ }^{78}$ ou com os órgãos integrantes do sistema nacional de crédito rural. ${ }^{80}$

Não podem os particulares, entre si, em suas operações, utilizar qualquer desses tipos de cédulas hipotecárias. Para eles ficou reservada, apenas, a hipoteca tradicional da qual não se extrai nenhum título hábil para fazê-la circular. Constitui, entretanto, má política permitirem-se somente a certas entidades poder lançar mão em seus negócios, de cédulas hipotecárias, pois nenhum argumento existe para restringi-las deste modo. No Projeto Orlando Gomes 81, previu-se a possibilidade de extrair uma cédula, mas não se regrou a figura, indicando apenas que ela se regularia por lei especial e se lhe aplicaria, no que coubesse os preceitos relativos à cédula rural pignoratícia. É de toda conveniência que o Código Civil regre, pela sua importância em nossos dias, a estrutura dessas células, como o fez o BGB, ao recolher os diversos sistemas hipotecários então existentes, como o prussiano, o bávaro e o renano, etc.

\section{O Princípio da Indivisibilidade}

15. O axioma da indivisibilidade da hipoteca tem sido posto em rude prova em face de novas necessidades. O

79. O DL 70 permitiu a extração de cédula hipotecária para as operaçōes compreenral, ou entre outras partes, desde que emitidas em favor de pessoas furídicas geaçam parte das "instituiçóes financeiras", ou de companhias de seguro (art 10, inc. I a III). Também a cécula de credito industrial somente ê utilizáve

80. A lei n.o 4.829, de 5 de novembro de 1965 criou o crédito rural e definiu que se deveria ter como tal, no artigo 2.0, restringindo o conceito a recursos inanceiros supridos por entidades públicas e estabelecimentos de crédito part1culares. A cédula rural hipotecária somente pode ser emitida por particulares,
no âmbito fixado pelo artigo 2.0 da lei 4.828 a cujos preceitos 0 DL. 167 vi. sou atender.
Artigo 695 e unico. princípio diz respeito ao crédito, o qual fracionado, não divide o gravame, e também ao imóvel onerado, pois ainda que este se tenha dividido, esse fato não se projeta sobre a hipoteca. A regra da indivisibilidade não é cogente, ou de "ordem pública" e sim dispositiva, já que as partes podem tornar o gravame divisível. O DL. 70 ao criar as cédulas hipotecárias determinou que o credor poderia emiti-las ${ }^{82}$ como cédula integral, representando a totalidade do crédito, ou fracionária, limitada a parte dele, sendo que essas últimas não podem exceder, em hipótese alguma, o valor total do crédito hipotecário. ${ }^{83}$ Deu-se ao credor a faculdade de fracionar o crédito e consequentemente emitir títulos até o limite total independentemente de concordância do proprietário do prédio gravado. O exercício dessa faculdade pluraliza os créditos, mas não constitui lesão ao princípio da indivisibilidade da hipoteca, pois cada uma delas tem como garantia o imóvel em sua totalidade.

A indivisibilidade da hipoteca significa também que os pagamentos parciais da dívida não autorizam a sua redução, ainda que ela compreenda vários bens. ${ }^{84}$

No Projeto Orlando Gomes ${ }^{85}$ previu-se a possibilidade de redução do gravame, não se restringindo como fez o Có digo Civil de Portugal às hipotecas judiciais. ${ }^{86}$ Hipótese de maior alcance é a da oneração dos prédios em construcão e a dos terrenos destinados a loteamento. No direito suíço, só se admite que vários prédios sejam dados em garantia de um só crédito se pertencerem a um proprietário, ou se forem de propriedade de vários devedores solidariamente obrigados. Nos demais casos, de hipoteca de vários prédios por um só crédito, deve ser cada um deles onerado com uma fração correspondente ao débito. ${ }^{87}$

Na edificação para venda de apartamentos e nos loteamentos surge o problema com maior intensidade, pois a hipoteca inicialmente se projeta sobre todo o terreno e posteriormente sobre os apartamentos e os lotes. O credor, em razão da indivisibilidade, retém em seu favor a hipoteca, gravando todos os apartamentos e terrenos, não sendo possível a remição parcial, como disposto no artigo 766 de nosso Código Civil, quando forem alienados. Todas essas realidades exigem um abrandamento do princípio da indivisi

82. DL. 70, artigo 10.

83. DL. 70, artigo 10 .
84. Código artigo 10, unicc
8ivil, artigo 758 .

84. Código Civil, artigo 758 .
85. Artigo 655.

86. Cód. Civil português, artigo 720 A A redução das hipotecas voluntárias supóe

87. $\mathrm{ZBE}$, artigo 798 
bilidade, com a sua aplicação em outras hipotecas, que não foram previstas no Projeto Orlando Gomes. Nenhum prejuízo adviria ao credor se, realizado o loteamento ou a edificação, fosse possível aos adquirentes, na proporção do valor de seu prédio ou de seu terreno, restringir a hipoteca à fração por eles adquirida, inclusive para poder remi-la. Seria, em consequência, um ato complementar à venda dos lotes ou à individualização do edifício. Para isso não se faria necessário que o devedor hipotecário já houvesse pago a metade da dívida como se previu no $\S 1^{9}$ do artigo 655 do Projeto Orlando Gomes.

o direito germânico conhece a hipoteca em comum, ou em mão comum, quando o gravame abrange vários prédios de diferentes proprietários. ${ }^{88}$ Se a hipoteca recair em vários prédios de um só proprietário, não se tratará evidentemente, de um gravame em comunhão. A natureza jurídica dessa hipoteca, no direito germânico, tem sido objeto de inumeráveis discussões, havendo quem afirme constituir uma espécie de comunhão "em mão comum", 89 ou uma comunhão segundo quotas. ${ }^{90} \mathrm{O}$ certo é que a alínea 2.a do $\& 1.172$ deu a cada um dos proprietários, desde que diversamente não haja sido disposto, o direito de exigir a redução da hipoteca que grava o seu prédio à fração correspondente à relação dele com o da totalidade dos prédios gravados. Esse dispositivo é do maior alcance, pois vem resolver precisamente os casos em que se edificou um prédio de apartamentos para vender ou se realizou um loteamento; em nosso direito ficaria na dependência do credor. As regas da hipoteca em comunhão ("Gesamthypothek") serviriam para resolver as dificuldades anteriormente expostas, e existentes em nosso direito, e para todas as demais em que houvesse uma pluridade de prédios de mais de um proprietário, garantindo somente uma relação creditícia.

$\mathrm{O}$ princípio da indivisibilidade das garantias reais, no pertinente à hipoteca, tem de ceder no sentido de permitir a redução do gravame hipotecário, quando efetuados pagamentos substanciais, e também quando se cuidar de edifícios para venda de apartamentos ou de loteamentos, pois é de todo interesse do adquirente que grave o prédio apenas a fração que corresponda à totalidade dos prédios hipotecados.

88. BGB, $\$ 1.132 ; \$ \S 1.172$ e seguintes
89. Staudinger.Kəber, Kommentar, III, $\$ 1.172$ página 884
90. Soergel_Baur, Kommentar, v. $4, \$ 1.172, \quad$ página 705
A divisão dará lugar ao aparecimento de várias hipotecas, cada uma delas vinculada a um imóvel determinado. A solução do § 1172 do BGB é bem melhor do que a do art. 798 do Cód. Civil suiço, porque esta apenas permite, no caso de hipotecas de vários prédios por um só débito, pertencentes a diversos proprietários não obrigados solidariamente, que o ônus real grave cada um deles, segundo a fração que lhe caiba no débito total. No $\$ 1.172$ do BGB conferiu-se a cada um dos proprietários o direito formativo modificativo, de fracionar a hipoteca que grava a totalidade, de modo a que o seu prédio fique gravado apenas com uma parcela correspondente ao todo.

\section{Os Pactos de Reserva Prelatícia}

16. Sempre foram admitidos, em nosso direito, os pactos de reserva prelatícia, ou de reserva de prioridade de ônus, ${ }^{91}$ por se localizar a faculdade na ampla faixa de autonomia da vontade. A dificuldade está, porém, em fixar seus efeitos, se reais, ou meramente obrigacionais.

Toda a sistemática do registro, nesse particular, atende a dois princípios fundamentais, o da prioridade e o da continuidade. Convém, desde logo frisar, que a adoção da reserva de prioridade de ônus tem valor econômico relevante e atende às necessidades do crédito imobiliário visto que algumas instituições financeiras somente operam com gravames de primeiro grau. A "posição" dos gravames entre si quem a dá é o número de ordem e daí decorre normalmente a prioridade dos direitos reais em relação a outros inscritos posteriormente. Em algumas legislações, não se atribuiu ao proprietário a faculdade de reservar para outrem, mediante negócio jurídico com o credor, a preferência. Mas em outras, a precedência entre os direitos reais depende em princípio da "posição" no registro imobiliário, embora seja possível, por meio de negócio jurídico dispositivo, conferir-se prioridade a direitos reais a serem inscritos posteriormente. No caso, a "posição" em que se encontra o credor hipotecário no registro não significa que ele tenha preferência, pois se destacou da anterioridade do número de ordem e efeito que Ihe é normal, para atribuí-lo a outrém.

No DL. 1.000 , reitera-se, no artigo 193, a regra constante no artigo 206 do anterior "Regulamento dos Registros Públicos", segundo a qual, apresentado o título da segunda hi91. Pontes de Miranda, Tratado de Direto Privado, v. 18, páginas 38 e seguntes
Carvalho dos Santos, Repertorio Enciclopédico do Direito Brasileiro, ve 25, vb. Carvalho dos Santos, Repertori
Hipoteca, pagina 20 e seguintes. 
poteca com referência à existência de anterior, o oficial, depois de prenotá-lo, esperará trinta dias que o interessado na outra promova o registro, com a devida preferência". Se tal não ocorrer, acrescenta o DL. 1.000, isto é, "esgotado esse prazo, que correrá da data da apresentação, sem que apareça o primeiro título, o segundo será registrado e obterá preferência sobre aquele". Discute-se se o princípio é dispositivo e Pontes de Miranda o considera modificável pelas partes..$^{92} \mathrm{O}$ artigo 245 do DL. 1.000 consagra axioma igual ao artigo 262 do anterior Regulamento dos Registros Públicos, no qual se afirma que "a prioridade das hipotecas de qualquer natureza será regulada exclusivamente pelo número de ordem do protocolo, ressalvadas as hipóteses dos artigos 193 e 195". A fixação da natureza e da eficácia dos pactos de reserva prelatícia dependem de ser ou não constitutivo o registro. Se ele possuir o predicamento da constitutividade, nenhum óbice haverá quanto à utilização dos aludidos pactos, salvo se existir proibição.

Se for vedado outorgar-se prioridade diversa do número de ordem, o pacto de reserva prelatícia terá somente eficácia obrigacional, impedindo, nesse plano, que o credor inscreva o ônus, mas nenhuma influência terá na dimensão dos direitos reais, de tal modo que se o credor entender de não cumprir sua obrigação, poderá ser constrangido a indenizar os prejuizos daí decorrentes, embora isso não se reflita quanto à prioridade por ele adquirida no momento em que requereu o registro. Nos códigos em que a hipoteca existe "inter partes", antes de ser inscrita, tem-se que o pacto de reserva de prioridade não depende de registro para sua existência ou eficácia, que é de direito real, mas "inter partes", tornando-se "erga omnes", realizada aquela providência.

$\mathrm{O}$ artigo 245 do DL. 1.000 fixa o princípio da imodificabilidade convencional dos graus de prioridade no registro, abrindo, apenas, no que aqui interessa, uma exceção, ou seja, a do artigo 193, correspodente ao artigo 206 do anterior Regulamento dos Registros Públicos.

A espécie prevista no artigo 193 constitui-se em germe imperfeito dos pactos de reserva prelatícia dotados de eficácia real. Prénotada hipoteca em que se alude à existência de outra, o oficial esperará por trinta dias, findos os quais será feita a inscrição. Os negócios jurídicos de reserva de grau atendem à necessidade de nossos dias de que o imóvel

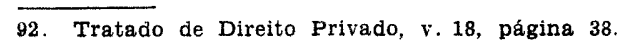

seja fator de crédito, cuja obtenção dura sempre período bem maior do que o previsto no artigo 193 do DL. 1.000 .

o Código Civil português não normou a figura, mas permitiu a cessão do grau hipotecário dos credores entre si $^{{ }^{3}}$ $O$ direito germânico além de regrar essa hipótese, ${ }^{94}$ disciplinou os negócios jurídicos de reserva de grau, ${ }^{95}$ que são de direito das coisas. No sistema do BGB, o proprietário, por meio de um negócio jurídico dispositivo com o credor, pode reservar-se o direito de inscrever com anterioridade de eficácia outra hipoteca, conforme as condições estabelecidas entre ambos. Sistema diverso seria o de registrar a hipoteca, objeto da reserva, com exclusão do eventual e futuro credor, para posterior complementação. Esta foi a solução do direito bávaro anterior portanto ao BGB. ${ }^{96}$

Poder-se-ia, por fim, aperfeicoar a disposição constante no artigo 193 do DL. 1.000 permitindo-se, no caso de existir um pacto de reserva prelatícia, que se faça a pré-notação da hipoteca e do aludido pacto, o qual há de conter as condicões gerais do gravame a ser posteriormente inscrito. A inscrição da hipoteca ficaria pendente durante o período estabelecido, mas se tornaria imediatamente eficaz se o imóvel fosse alienado, ou se se pretendesse registrar outra hipoteca sem as condições expressamente determinadas no pacto de reserva prelatícia. Essa solução aproximaria o tratamento do pacto de reserva de grau ao do das hipotecas diferidas, existentes em alguns sistemas modernos, as quais têm a característica de que a inscrição somente se opera quando o proprietário tentar registrar ou inscrever algum negócio jurídico capaz de prejudicar direitor do futuro credor hipotecário. Na hipoteca diferida não se faz desde logo a inscrição, mas os títulos necessários para isso estão em poder do oficial de registro, aguardando apenas a ordem, ou a ocorrência de algum fato que possa prejudicar os interesses do credor, tornando ineficaz a hipoteca a ser inscrita ou lhe dando categoria inferior à da data da entrega dos documentos. Com essa disposição, poder-se-ia impedir que a pré-notação tivesse eficácia apenas pelo período de trinta dias, o que é totalmente sem sentido em face das necessidades de obtenção de crédito imobiliário, as quais exigem espaço de tempo muito superior. A sua vez, constitui problema de não fácil solução o da extinção dos direitos reais pelo transcurso de tempo. Nas legislações que dão à constitutividade 93. Código Civil, artigo 729

94. BGB, \& 880

95. BGB, \& 881
96. Staudinger_Kober, Kommentar, III, \& 881, página 133. 
do registro um caráter absoluto, a inscrição de algum ônus ou gravame, de modo igual ao que sucede com a transcrição das alienações, não perde a sua eficácia apenas porque fluiu certo período de tempo. Esse princípio liga-se com o axioma de que as retificações do registro, quaisquer que sejam elas, dependem de provocação do interessado, não realizando o oficial nenhuma modificação "ex officio". Afirma-se, em consequência, que a regra da extinção dos efeitos do registro pelo simples decurso de um prazo seja peculiar aos códigos que adotaram o princípio de que o registro tem efeitos meramente declaratórios, preponderando sobre a realidade que ali se contém as vicissitudes pelas quais pode passar o negócio jurídico que lhe deu causa. Por esse motivo, no direito germânico, em que se deu ampla eficácia à constitutividade do registro, a reserva de grau de inscrição não está submetida a nenhum prazo e adere de tal modo ao direito do proprietário sobre o imóvel, que o acompanha nas alienações.

O pacto de reserva prelatício não é objeto apenas de prènotação, mas ele deve ser inscrito juntamente com o gravame. Não se altera o "número de ordem" ("Post") da inscrição do ônus, apenas a hipoteca inscrita posteriormente prefere à anterior, por força do pacto de reserva de grau. ${ }^{97}$

A particulariaade de nosso direito em face do BGB está em que entre nós se restringiu a possibilidade de alterar, por negócio jurídico, os graus de prioridade do registro, adotando, entretanto, quanto ao mais, um sistema móvel, já que, segundo a jurisprudência, no caso de vários credores hipotecários, o pagamento a um deles, ao credor da primeira hipoteca por exemplo, melhora a situação dos demais, porque o devedor não adquire em seu favor a hipoteca e as demais decrescem de grau.

No sistema do BGB, as hipotecas não modificariam nessa última hipótese a sua posição, pois o proprietário que prestou e solveu o débito adquiriria o gravame em seu favor, ${ }^{98}$ mantendo o seu grau. A vantagem para o proprietário é relevante, uma vez que ele poderá ceder o ônus real a outrem, com o grau em que estava inscrito.

O direito brasileiro adotou uma posição intermediária e não satisfatória, pois segundo o artigo 193 "in fine" do DL. 1.000 não apresentado acordo de constituição de hipoteca no prazo de trinta dias o oficial inscreverá a que lhe foi entregue como primeira hipoteca, perdendo o credor da outra a prefe-

$\begin{array}{ll}\text { 97. } & \text { Eichler, Institutionen, Ir, 2, página } 362 \\ \text { 88. } \$ 1.163 \text { do BGB }\end{array}$ rência. Cuida-ss, aqui, apenas da perda de preferência de direito reai, porque se o credor da segunda hipoteca se houvesse obrigado a não levá-la a registro antes que o da primeira o fizesse e se o prazo convencionado para isso fosse superior a trinta dias, o fato de o credor da segunda haver levado o título ao albo imobiliário seria, desde logo, infringência aos efeitos obrigacionais do pacto de reserva prelatí cia, devendo, se disso resultou algum prejuízo, indenizar.

Em nosso Código Civil, no artigo 817,99 determinou-se que perfazendo 20 anos só poderá subsistir a hipoteca recunstituindo-se por novo título e nova inscrição e, neste caso, lhe será mantida a preferência, que então lhe competir Esta hipótese era a única em nosso direito, em que a extinção de uma hipoteca não alterava a ordem de precedência, quando se renovava o título e o próprio registro. Todavia, em face do artigo 245 do DL. 1.000 que ressalvou apenas dois casos em que a aludida precedência não se regularia pelo número de ordem (artigos 193 e 195) e não constando entre elas a preferência do artigo 817 do Código Civil, em sua parte final, tem-se que a mesma foi derrogada pelo aludido Decreto-lei.

Por fim, a legislação sobre registros públicos não adotou, senão em escassa medida, a modificação convencional dos graus de prioridade por meio de pactos de reserva prelatícia, como também não normou a cessão dos graus hipotecários entre os credores. O pagamento do crédito hipotecário faz com que o gravame se extinga, sem que se transforme em ihpoteca em favor do proprietário, o que seria uma solução prática e de grande alcance econômico.

\section{O Direito de Remição}

17. O direito de remição, no direito brasileiro, cabe ao credor da segunda hipoteca, ao próprio devedor ${ }^{100}$ e ao adquirente. ${ }^{101}$

A particularidade de nosso direito, do italiano e do português, para somente enumerar alguns sistemas jurídicos, está em que o adquirente do imóvel gravado tem o direito de remi-lo antes do vencimento do crédito hipotecário. ${ }^{102} \mathrm{Na}$ "common law" inglesa, denomina-se de remição também ao dever que tem o obrigado de adimplir a dívida, mas isso atende à peculiaridade de que nesse sistema o credor pode 99. Com a redacão dada pela Lei no 2.437, de 7 de março de 1955. 101. Código Civil artigo 814 102. Código Civil, artigo $815, \& 10$ 
tornar-se proprietário através de declaração judicial de preclusão do direito de remir e também à concepção vigorante até o advento da "Law Property Act", em 1925, de que na hipoteca se transferia desde logo a propriedade ao credor, embora sob condição resolutiva, ficando, em princípio, o devedor hipotecário com a posse imediata.

No direito germânico, ${ }^{103}$ deu-se o direito de remição "Ablösungsrecht" ao proprietário do bem gravado que seja também devedor e a qualquer terceiro que possa perder, por meio da execução hipotecária, um direito no imóvel, incluindo-se, entre eles, o possuidor que sofrer o risco de se ver privado da posse. ${ }^{104}$

Merece crítica considerar-se exercício de direito de remir o adimplemento do devedor que seja ao mesmo tempo proprietário do imóvel onerado, pois nenhum direito existe para ser exercido, já que se trata precisamente do contrário, isto é, de cumprir um dever. Não haveria sentido em usar a expressão direito de remir, ou remição para essas hipotecas. 105

Em algumas legislações, o direito de remição, ou de expurgação de ônus, como lhe denomina o Código Civil português, ${ }^{106}$ é somente aplicável aos adquirentes de imóveis gravados, não se considerando os demais casos, como o do credor hipotecário, espécies do direito de remir.

O conceito do direito de remir dependerá dos efeitos que o ordenamento jurídico atribuir ao seu exercício. Nos códigos que dispuseram que a remição somente terá lugar quando um terceiro adquirir o domínio de um imóvel gravado, a remição terá o sentido de liberação, de extinção ou expurgacão de um gravame. Em outros sistemas, e isso se deduz pelo \& 268 do BGB, a remição se constitui em "direito à proteção de outros direitos" e o seu exercício supõe o vencimento da dívida hipotecária. Nosso Código Civil tem a remicão no sentido dos códigos romanísticos, isto é, independentemente do vencimento da divida quando o terceiro adquire imóvel gravado, propondo para a liberacão pelo menos 0 preço pelo qual obteve o bem, ${ }^{107}$ e também no do BGB.

Se o ordenamento admitir hipotecas em favor do proprietário, o exercício do direito de remir não gera imediatamente a liberação e apenas transfere a quem prestou a titularidade da garantia real. Mas, se do exercício do direito

103. $\mathrm{BGB}, \$ 1.142$ e seguintes
104. BGB, \$\& 268 e 1.1150.

105. H. Westermann, Sachenrecht, \$ 103 , páginas 499 e segs.
106. Código Civil, port, art. 721 ; "Códlgo Civil ital., arts. 2.889 e segs. resultar a consumpção da garantia, a remição terá o significado de liberação.

No direito brasileiro, cabe ao devedor, ao titular da segunda hipoteca e ao terceiro adquirente o aludido direito. Nas duas primeiras hipóteses, é necessário que a dívida esteja vencida e, na última, tem-se que o nascimento do direito de remir opera-se pelo simples fato da aquisição por terceiro de bem gravado.

A razão pela qual o ordenamento dá ao credor da segunda hipoteca o direito de remi-la outra não é senão a de impedir que o credor da segunda venha a sofrer o risco resultante de uma possível execução e o adimplemento que este realizar repercutirá no mundo jurídico como subrogação ${ }^{108}$ nos direitos do credor cujo débito foi solvido. Todavia, não parece acertado conferir esse direito apenas ao credor da segunda hipoteca, como se dispôs no direito brasileiro, pois a situação deste é análoga a de todos os demais que podem perder um direito sobre o imóvel, por força de uma execução hipotecária.

O direito de remir, no particular, liga-se com a teoria do pagamento ou adimplemento. Se todos e qualquer um pudessem prestar independentemente da vontade do devedor nenhum sentido haveria em falar-se em direito de remir, pois o pagamento teria sempre a virtude de liberar o ônus, embora pudesse não gerar a subrogação nos direitos do credor. No direito germânico, se o devedor objetar ou contraditar a oferta da prestação por terceiro, terá o credor a faculdade de recusá-la ${ }^{109}$ Todavia, se se tratar de exercício de direito de remição, o seu titular poderá prestar ainda que o devedor tenha objetado e que o credor se tenha recusado a aceitar o adimplemento. Distinguem-se, ai, nitidamente direito e faculdade; e a remição é exercício do direito.

No direito brasileiro não se vinculou o direito de remir com a teoria do pagamento e dispôs-se apenas a respeito de uma hipótese de remição, a do credor da segunda hipoteca, não se facultando aos demais detentores de um direito sobre o imóvel, o exercício do aludido direito.

Nosso Código submete a outros requisitos o direito de remir do terceiro, adquirente de imóvel gravado, já que este direito nasce independentemente do vencimento da dívida $\mathrm{e}$ a remição pode ser feita pelo valor da alienação.

No BGB, adotou-se uma norma igual para todas as hipóteses em que o imóvel gravado não pertence ao devedor 108. Código Civil, art. $814, \& 20$; art. 985 , inc. I
109. BGB, \& 267, alinea 2.a. 
hipotecário e pouco importará se foi um terceiro quem deu e garantia real, ou se alguém posteriormente adquiriu a propriedade gravada, pois o tratamento jurídico é o mesmo.

Conforme disposto no $\$ 1.172$, o proprietário está legitimado a satisfazer o credor quando o crédito se venceu ou quando o devedor pessoal tenha o direito a efetivar a prestação.

Tanto a "common law" quanto o direito germânico desconhecem o benefício de poder utilizar o adquirente do imóvel gravado o direito de remição antes ainda do vencimento da dívida, pois este direito somente pode ser exercido como está expresso com mais generalidade no BGB, desde que possa haver a execuçâo hipotecária, ${ }^{110}$ uma vez que existem causas de denúncia do contrato por descumprimento de obrigações.

Cuida-se então, de saber, da compatibilidade do direito de remição com a circulação das hipotecas por meio de cédulas. $O$ direito dos adquirentes dos imóveis gravados de liberarem-se do ônus sem que a dívida esteja vencida dificulta a circulação hipotecária, pois submete ao credor ao de ver de, se não concordar com a oferta do valor da remição, que é pelo menos o da aquisição, ter de submeter-se a um pro cesso de limitação. ${ }^{111}$ Apesar de ser a remição o exercício de um direito, o Código Civil, paradoxalmente, onera-o de tal modo se não notificar o credor dentro em trinta dias a con tar da data da aquisição para esse efeito, ${ }^{112}$ que ele tem de iniciar o processo de liberação do imóvel. Como este pode ser liberado propondo-se o preço pelo qual foi obtido, tudo isso pode resultar em grave prejuízo para o credor e para as demais transações que tenham por base a cédula hipotecária. Não seria, em consequência, aconselhável permitir o exercício do direito de remição antes do vencimento da dívida, ou sem que o imóvel estivesse sofrendo o risco de vir a ser executado, pelo menos nas hipotecas cedulares.

Se quem adquiriu prestar ao credor, operar-se-á em seu beneficio, e de pleno direito, a subrogação. ${ }^{113}$ Se quem tornar-se proprietário do prédio, em razão da licitação, for o credor hipotecário, o devedor e alienante será responsável por evicção, ${ }^{114}$ em face daquele que perdeu o domínio.

No direito italiano, ${ }^{115}$ deu-se a faculdado ao adquirente

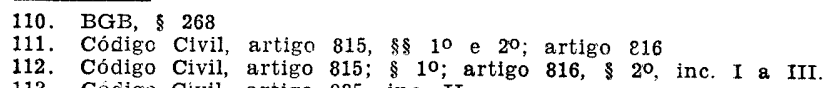

113. Código Civil artigo $815 ;$ \& 10 ;

114. Código Civil, artigo 816, \& 40; artigo 1.108
115. Código Civil ital., artigo 1.482; artigo 2.897.

130 do imóvel hipotecado, no momento em que o compra, de reter a prestação do preço para ofertá-la ao credor. Com esse procedimento, evita-se que haja uma nova prestação do adquirente, com a qual ele se subrogaria nos direitos do credor em face do devedor a tenha depois de cobrar deste o que pagou.

costume, entre nós, de que na alienação haja também uma "assunção interna de adimplemento", pela qual o novo proprietário, como parte do preço, promete ao vendedor quitar a hipoteca. Nessa hipótese, não se pode falar em pagamento que gere subrogação, pois parte ou a totalidade do preço tem de ser pago ao credor hipotecário. Cuida-se de estipulação em favor de terceiro "solvendi causa", normalmente em sentido impróprio, uma vez que a "assunção interna de adimplemento" é negócio jurídico somente entre devedor e terceiro e não gera direitos ao eventual beneficiário, no caso, ao credor hipotecário.

A posição jurídica do adquirente de um imóvel hipotecado é a mesma de quem não é devedor e deu em garantia de um débito um imóvel de sua propriedade. A identidade entre ambos os casos está em que eles não devem, apenas respondem. Tudo isso, está a exigir um tratamento igual.

\section{Os Representantes para fins de Execução Extrajudicial}

18. Determinou-se no artigo 29 do DL. 70 que "as hipotecas a que se referem os artigos 9 e 10 e seus incisos, quando não pagas no vencimento, poderão, à escolha do credor, ser objeto de execução na forma do Código de Processo Civil (artigos 298 a 301) ou deste Decreto-lei (artigos 31 a 38 )"

A execução das cédulas hipotecárias ${ }^{11}$ pode ser realizada através de "agentes fiduciários", sendo um deles, para as hipotecas compreendidas no Sistema Financeiro da $\mathrm{Ha}$ bitação, o Banco Nacional de Habitação (BNH) e, nos demais casos, as instituições financeiras, inclusive as sociedades de crédito imobiliário. ${ }^{117}$ Os agentes fiduciários, nas hipotecas não compreendidas no Sistema Financeiro de $\mathrm{Ha}$ bitação, deverão ser escolhidos de comum acordo entre credor e devedor, no contrato originário ou em aditamento ao mesmo, salvo se estiverem agindo em nome do $\mathrm{BNH}$, como

116. DL. 70, artigos 9 e 10
117. DL. 70, artigo $30, \mathrm{I}$ e Ir. O termo agente fiduciário provém da "common law"
117. DL. 70 , artigo 30 , I e II. O termo agente fiduciário provém da "common law" DL. ro, artigo 
delegados para esse efeito, ${ }^{118}$ ou nas hipóteses em que não havendo acordo sobre quem deverá ser agente fiduciário seja o mesmo designado pelo juiz competente. ${ }^{119}$ No processo de execução de cédulas hipotecárias por meio de agentes fiduciários, ou de representantes, adotou-se o modelo de execucão forcada, pois embora ela se realize extra-judicialmente, ela se efetiva através de leilões públicos, guardando semelhança com o que ocorre nas execuções judiciais. ${ }^{120} \mathrm{Em}$ sua essência, esse tipo de execução extra-judicial é análogo ao das "mortgages" do direito americano em que o credor, ${ }^{121}$ ou um terceiro, inclusive órgãos públicos, desde que assim se tenha convencionado, têm legitimação para realizar a extraçâo do valor do imóvel, como fiduciário do credor e do devedor, sendo autorizados a receber quantias e a realizar pagamentos, tal como se previu no DL. 70.122

No sistema DL. 70, o representante de ambos os figurantes da relacão de crédito hipotecário é fiduciário não só do 'power of sale', como também dos "proceeds of sale", devenđo, para isso, realizar leilões públicos, o que não sucede, em princípio, no direito inglês.

No DL. 70, previram-se dois tipos de agentes fiduciários em seu artigo 30 , sendo o do inciso $\mathrm{I}$, o $\mathrm{BNH}$, de natureza diversa dos demais. É da competência do BNH, nas hipotecas compreendidas no Sistema Financeiro de Habitação, a qualidade de agente fiduciário, por força de lei, se optar pela execução extra-judicial ${ }^{123}$ independentemente, portanto, de acordo entre os figurantes da relação jurídica. ${ }^{124}$

Essa competência é de direito público e pode ser delegada às instituições financeiras ${ }^{125}$ pelo Conselho de Administração do BNH, o qual lhes fixará a forma de atuação.

Nos demais casos, o agente fiduciário depende da concordância do credor e devedor, ou ainda de indicação judicial, se não houver acordo. Sua posição é, entretanto, mais restrita do que a do "Grundbuchvertreter", pois o representante inscrito no albo imobiliário não é figura que surja apenas na execução da hipoteca, mas um representante com características de fiduciário que pode acompanhar todo o desenvolvimento da relação obrigacional e hipotecária, res-

118. DL. 70, artigo $30, \&$ único.

120. DL. 70 , artigos 32 a 34

1. No DL. 70, salvo quando se culdar do BNH como "agente fiduciário" por natureza ser sempre um tereiro que não mantenha vinculos com credores 22. DL. 70 , artigo 35

123. DL: 70 , artigos 29 e 10 , inc.

124. DL. 70 , artigo $30, \& 20$ trito, é verdade, aos gravames em segurança de titulos aos portador, letras de câmbio ou outros títulos endossáveis.

A posição jurídica do agente fiduciário, escolhido por ambos os figurantes, é peculiar: não se vincula ao proprietário ou ao credor, por uma relação de mandato. Ele representa a ambos por direito autônomo tal como sucede com o representante inscrito no albo imobiliário, no direito germânico, ${ }^{12 \epsilon}$ embora lá não se admita a execução extra-judicial da hipoteca. E' o que se deduz também do artigo 35 do DL. 70 , em que se afirma ser o aludido agente "autorizado independentemente de mandato do credor ou devedor, a receber quantias que resultarem da purgação do débito ou do primeiro ou segundo público leilões, que deverá entregar ao credor ou ao devedor conforme o caso, deduzidas de sua própria remuneração"

O agente fiduciário tem, entretanto, poderes menos amplos, posto que vinculados somente à execução hipotecária extrajudicial. O próprio BNH reconheceu essa insuficiência tanto que por Resolução de Diretoria ${ }^{127}$ criou a figura dos "cobradores", aos quais compete o recebimento do crédito corporificado nas cédulas hipotecárias.

No direito germânico, todas essas funções, de cobrança, de fiscalização, de denúncia do contrato hipotecário e de execução, podem ser atribuídas ao representante. Para constituir o representante inscrito no registro imobiliário, é necessário, segundo o BGB, também acordo entre o proprietário e o credor se o título for a ordem; se se tratar de título ao portador, basta a declaração de vontade de quem tern o domínio, exigindo-se em ambos os casos a inscrição no registro de imóveis. ${ }^{128}$

A instituição de representante inscrito no albo imobiliário, que pode ser pessoa física ou jurídica, tem por finalidade tornar ao devedor mais fácil a prestação, principalmente quando se cuida de títulos amortizáveis e evitar que este não saiba, em face da circulação do título, quem deverá receber a prestação.

No DL. $70{ }^{129}$ facultaram-se às partes, em qualquer momento em aditamento ao contrato hipotecário, substituir o agente fiduciário. A substituição convencional do agente supõe apenas acordo entre credor e proprietário e refere-se, obviamente, àqueles casos em que a indicação do represen-

126. Staudinger-Kober, Kommentar, III, $\$ 1.189$, VI, pág. 949

RD, 16/67.

$\begin{array}{llll}\text { 128. } & \mathrm{BGB}, \$ 1.188 . \\ 129 . & \mathrm{DL} .70, \text { artigo } & 30,84^{\circ}\end{array}$ 
tante é convencional. De modo igual, pode ocorrer, no direito germânico, mediante acordo entre proprietários e credores, a destituição do representante, devendo, entretanto, esse acordo, para produzir efeitos, ser levado a registro.

O direito brasileiro demonstra assim uma aproximação progressiva à figura do representante, com poderes mais extensos do que o de simples "agente fiduciário". Seria de toda conveniência dar maior dimensão a essa figura atribuindo-lhe um sistema de regras claramente definido. Um bom modelo para isso poderia ser o representante inscrito no registro de imóveis, abrangendo não só as hipotecas em garantia do DL. 70, mas também as hipotecas de tráfico, previstas nos DLs. 167 e 413, facilitando os recebimentos das quantias para amortização ou quitação, regularizando a todo o momento o registro em razão da circulação, como também conferindo-lhe a representação para execução judicial ou extra-judicial até final extração do valor do bem onerado.

\section{Hipoteca e Anticrese}

19. No direito inglês, a "mortgage" contém, como uma virtualidade de execução do débito, a transferência da posse imediata ao credor para que este possa fruir as utilidades do bem e compensar os juros ou o capital. No direito brasileiro, há uma certa tendência para a extinção da anticrese. Uma das razões de não ser aplicável entre nós a anticrese está em que o seu regramento, ao contrário do usufruto, não permite que essa garantia recaia sobre universalidades. Por sua vez, impunha-se que o Código Civil houvesse exarado certas regras sobre a administração, prestação de contas e até mesmo, como sucede no direito inglês, sobre a possibilidade de ser fixado judicialmente o preço do arrendamento que compensasse a utilização do imóvel. Deixar ao arbítrio do credor essa providência, torna extremamente desinteressante o instituto. O Projeto Orlando Gomes não consagrou a anticrese entre os direitos reais da garantia, seguindo, aliás, o exemplo do Código Civil português. Os direitos do usufrutuário, no Projeto Orlando Gomes, podem ser cedidos a terceiros, resolutivamente, tendo o nú-proprietário direito de preferência na aquisição ${ }^{130}$ de modo que esses direitos podem ser objetos de hipoteca. ${ }^{131}$

130. Artigo 533 e único. No Projeto Orlando Gomes consagra_se principio diverso

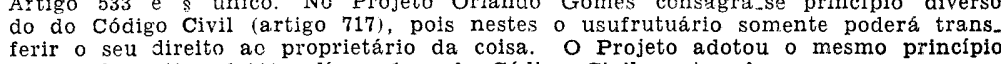
ferir o seu direito ac propritetario da colsa. O Projeto adotou o mesmo principio
que o do artigo 1.444, alinea 1.a, do Código Civil português.
Projeto Orlando Gomes, arts. 644 e 647; Código Civil port., art. 689, alíneas 1 a 3
Todavia, não parece acertado extinguir a anticrese, quando em outros países ela tem sido aplicada até mesmo no direito de empresas, com excelentes resultados. O BGB não contemplou a anticrese no catálogo dos direitos reais de garantia sobre imóveis, mas a praxe criou o denominado "usufruto em garantia", por meio do qual se pode atribuir ao credor hipotecário o usufruto sobre o bem gravado, para desse modo imediatamente (e não após o "sequestro") poder fruir os frutos do imóvel (por exemplo, os aluguéis). ${ }^{132}$ Os frutos destinam-se a abater a dívida garantida por hipoteca. Com a combinação dessas duas figuras, hipoteca e usufruto, chegou-se à permissão fática da anticrese sobre bens imóveis que o BGB não consagrara, pois o "penhor de fruição" somente pode recair sobre bens móveis. Nosso Código Civil define a anticrese ${ }^{133}$ como direito de real garantia através do qual o devedor, ou um terceiro, entrega ao credor um imóvel, cedendo-lhe o direito de perceber, em compensação da dívida, os frutos e rendimentos. Essa definição corresponde a da "vifgage", e a do $\$ 11^{\text {0 }}$ do artigo 805 a da "mortgage" medieval, já que é lícito estipular também que os frutos e rendimentos do imóvel, na sua totalidade, sejam percebidos pelo credor somente à conta de juros. Em nosso direito, permite-se que o imóvel hipotecado possa ser dado em anticrese pelo devedor ao credor ihpotecário, assim como o imóvel sujeito à anticrese possa ser hipotecado pelo devedor ao credor anticrético. ${ }^{134}$

Critica-se a anticrese por não ser utilizada em nossos dias. A verdade é que a anticrese, no Código Civil, restringiu-se aos frutos e rendimentos produzidos por imóveis, o que não satisfaz numa época predominantemente industrial, na qual a empresa tende a ser o centro da economia. Assim, impunha-se que objeto de anticrese pudessem ser

\section{Substitutivo ao direito hipotecário do Anteprojeto de \\ Código Civil, apresentado à Comissão Elaboradora \\ e Revisora do Código Civil.}

\section{Dos Direitos Reais de Garantia}

Artigo ... - Nas dívidas garantidas por penhor, anticrese ou hipoteca, a coisa dada em garantia fica sujeita por vínculo real ao cumprimento da obrigação; salvo se a hipoteca houver sido constituída em favor do proprietário.

132. Baur, Sachenrecht, \& 32, I, b, página 260

133. Artigo 805. 
também empresas, ou seja, universalidades, tal como sucede com o usufruto.

Artigo ... - Só aquele que pode alienar, poderá hipotecar, dar em anticrese, ou empenhar. Só as coisas que se podem alienar poderão ser dadas em penhor, anticrese ou hipoteca.

§único - O domínio superveniente torna eficaz, desde a inscrição, as garantias reais estabelecidas por quem possuía a coisa a título de proprietário.

Artigo ... - A coisa comum a dois ou mais proprietários não pode ser dada em garantia real, na sua totalidade, sem o consentimento de todos; mas cada um pode individualmente dar em garantia real a parte que tiver, se for divisível a coisa, e só a respeito dessa parte vigorará a indivisibilidade da garantia.

\& único - Se o objeto do gravame for um imóvel que houver sido loteado ou edificado e se os adquirentes dos prédios ou terrenos forem várias pessoas, poderá o ônus ser fracionado e afetado a cada uma das propriedades, mediante pedido do credor ou do devedor ao juiz competente, na proporção de seu valor em face da totalidade do débito, desse que seja manifestamente superior ao crédito que lhe vier a corresponder.

Artigo ... - O pagamento de uma ou mais prestações da dívida não importa exoneração correspondente da garantia, ainda que esta compreenda vários bens, salvo disposição expressa no título ou na quitação.

\& único - Se o saldo da dívida for manifestamente inferior ao valor de um ou mais bens gravados, pode o devedor requerer ao juiz competente, ouvido o credor, a liberação do outro, desde que um terceiro, idôneo, se obrigue a adquiri-lo em iace do credor por valor pelo menos igual a totalidade da aludida divida.

Artigo ... - O credor hipotecário e o pignoratício têm direito de executar a coisa hipotecada, ou empenhada, e preferir, no pagamento, a outros credores, observada quanto à hipoteca, a prioridade na inscrição, salvo a existência de convençäo de reserva de grau hipotecário.

\& único - Excetuam-se, dessa regra, as dívidas que em virtude de outras leis devam ser solvidas com precedência a quaisquer outros créditos.

Artigo ... - $\mathrm{O}$ credor anticrético tem direito de reter em seu poder os bens, enquanto a dívida não for paga. Extingue-se, porém, esse direito decorridos quinze anos da data de sua constituição.
Artigo ... - Os contratos de penhor, anticrese e hipoteca declararão, sob pena de inexistência, ou de ineficácia, conforme o caso:

I - O total da dívida, sua estimação, ou o seu valor máximo.

II - O prazo fixado para pagamento, ou para execução real.

III - A taxa de juros, se houver.

IV - Os bens dados em garantia, ou a coisa gravada, com as suas especificações.

Artigo ... - A dívida considera-se vencida:

I - Se deteriorando-se, ou depreciando-se os bens dados em segurança, desfalecer a garantia, e o devedor, intimado, a não reforçar.

II - Se o devedor cair em insolvência, ou falir.

III - Se as prestações não forem pontualmente pagas, toda vez que deste modo se achar estipulado o pagamento. Neste caso, o recebimento posterior da prestação atrazada importa renúncia do credor ao seu direito de execução imediata.

IV - Se perecer o objeto dado em garantia.

V - Se se desapropriar a coisa dada em garantia,

depositando-se parte do preço, que for necessário para o pagamento integral do credor.

$1^{0}$ - Nos casos de perecimento ou deterioracão do objeto dado em garantia, a indenização, estanđo ele seguro ou havendo alguém responsável pelo dano, se subrogará, na coisa destruída ou deteriorada, em benefício do credor, a quem assistirá sobre ela preferência até o seu completo reembolso.

$\$ 2^{\circ}$ - Nos casos dos números IV e V, só se vencerá a nipoteca antes do prazo estipulado, se o sinistro, ou a desapropriação recair sobre o objeto dado $\mathrm{em}$ garantia, e esta não abranger outros; subsistindo, no caso contrário, a dívida reduzida, com a respectiva garantia sobre os demais bens, não desapropriados, danificados, ou destruídos.

Artigo ... - $\mathrm{O}$ antecipado vencimento da dívida nas hipóteses do artigo anterior, não importa o dos juros correspondentes ao prazo convencional por decorrer.

Artigo ... - Salvo cláusula expressa, o terceiro que presta garantia real por divida alheia, não fica obrigado 
a substituí-la, ou reforçá-la, quando, sem culpa sua, se perca, deteriore, ou desvalie.

Artigo ... - E' nula a cláusula que autoriza o credor pignoratício, anticrédico ou hipotecário a ficar com o objeto da garantia, se a divida não for paga no vencimento.

\section{Da Hipoteca}

Artigo ... - Podem ser objeto de hipoteca:

I - Os imóveis.

II - Os acessórios dos imóveis conjuntamente com eles.

III - O usuiruto.

IV - O domínio direto.

$\mathrm{V}$ - O domínio útil.

VI - As minas e pedreiras, independentemente do solo onde se acham.

VII - Os navios.

O usufruto pode ser objeto de hipoteca se for cessível a terceiros, que não o nú-proprietário.

Artigo ... - A hipoteca abrange todas as acessões, melhoramentos ou construções do imóvel. Subsistem os ônus reais constituidos e transcritos, anteriormente à hipoteca, sobre o mesmo imóvel.

Artigo ... - $\mathrm{O}$ dono do imóvel hipotecado pode constituir sobre ele, mediante novo título, outra hipoteca, em favor do mesmo, ou de outro credor.

Artigo ... - Salvo o caso de insolvência do devedor, o credor da segunda hipoteca, embora vencida, não poderá executar o imóvel antes de vencida a primeira.

$\S$ único - Não se considera insolvente o devedor, por faltar ao pagamento das obrigações garantidas por hipotecas posteriores à primeira.

Artigo -. A hipoteca anterior poderá ser remida em se vencendo, pelo credor da segunda e por todos aqueles que sofrerem o risco de perder um direito sobre 0 imóvel por força da execução e também pelo próprio possuidor, se o devedor não solver o débito.

$\S 1^{\circ}-O$ direito do credor da segunda hipoteca prefere $o$ dos demais, exceto o do adquirente, obedecendo-se, nos demais casos, para esse efeito, a antiguidade do título que o origina. $2^{\circ}$ - Aquele que solver o débito se subrogará nos direitos do credor hipotecário sem prejuízo dos que porventura lhe competirem contra o devedor comum.

Artigo ... - Ao adquirente do imóvel hipotecado cabe $o$ direito de remi-la antes ainda do vencimento da dívida, se não se acordou em extrair uma cédula.

$1^{\circ}$ - Se o adquirente pretender evitar os efeitos da execução, notificará judicialmente, dentro de trinta dias, o seu contrato aos credores hipotecários, propondo, pelo menos, o preço por que adquiriu o imóvel, desde que este seja igual ou inferior ao crédito.

$\S 2^{\circ}$ - Se o credor impugnar o preço da aquisição, ou a importância oferecida, realizar-se-á a licitação entre os credores hipotecários, os fiadores, os demais titulares de um direito sobre o imóvel, o possuidor, e o adquirente, efetuando-se a venda judicial a quem oferecer maior preço, assegurando-se a preferência a este último.

Artigo ... - Se o credor não recusar a importância que lhe foi oferecida, haver-se-á esta como definnitivamente fixada.

Artigo ... - Se 0 adquirente não promover a remição e sujeitar o imóvel a ser executado, ficará este obrigado a ressarcir aos credores hipotecários a desvalorização que, por culpa sua, o mesmo vier a sofrer.

Artigo ... - Disporá de ação regressiva contra o vendedor o adiquerente evicto mediante licitação ou penhora.

Artigo ... - Se a hipoteca houver sido constituída cedularmente, pode o adquirente do imóvel gravado e, nos demais casos, o executado até a assinatura do auto de arrematacão, ou até que seja publicada a sentença de adjudicação, liberar o imóvel oferecendo preço igual ao da avaliação, se não tiver havido licitantes, ou ao de maior lanço oferecido.

Artigo ... - No caso de falência do devedor hipotecário, o direito de remissão devolve-se à massa, em prejuízo da qual não poderá o credor impedir o pagamento do preco por que foi avaliado o imóvel. O restante da dívida hipotecária entrará em concurso com as quirografárias.

No caso de insolvência, cabe aquele direito aos credores em concurso.

Artigo ... - Pode o credor hipotecário, no caso de insolvência ou falência do devedor, para pagamento de sua dívida, requerer a adjudicação do imóvel, avaliado em 
quantia inferior a esta, desde que dê quitação pela sua totalidade.

Artigo ... - São nulas, em benefício da massa as hipotecas celebradas, em garantia de débitos anteriores, nos 40 dias precedentes à declaração de quebra ou à instauração de concurso de preferência.

Artigo ... - E' nula a venda judicial dos imóveis gravados por hipotecas devidamente inscritas sem que tenham sido notificados judicialmente todos os que tenham o direito de remi-los, que não houverem sido de qualquer modo partes na execução.

\section{Das Cédulas Hipotecárias}

Artigo ... - Podem credor e proprietário, no acordo de constituição de hipoteca, permitir que o oficial do registro de imóveis competente extraia uma cédula hipotecária, que será por ele autenticada e averbada.

Artigo ... - A cédula hipotecária deverá conter - nome do proprietário e do credor, se o título não for extraído em benefício daquele, o montante da dívida, o seu vencimento, os juros se houver, o imóvel, com o número de sua transcrição, com suas dimensões e localização, o número de ordem da inscrição hipotecária, o seu grau e a existência, ou não, de pacto de reserva de prioridade.

\& único - A cédula hipotecária pode ser extraída pela totalidade do crédito, ou fracionariamente se assim houver sido convencionado.

Artigo ... - A transferência da cédula operar-se-á por endosso nominal, mas a substituiç̃o dos credores, bem como as modificações na garantia real, só se tem como existentes se houverem sido averbadas no registro próprio Artigo ... - No caso de divisão do gravame, serão notificados todos os credores hipotecários para substituírem seus títulos por outros a serem extraídos pelo oficial do registro onde se realizou a inscrição, em conformidade com o que nela constar.

Artigo ... - Faculta-se ao credor e ao proprietário, no acordo de constituição de hipoteca, determinar que as modificações no conteúdo da garantia e as substituições de seus titulares acompanham as da relação de crédito e independem de averbação no registro próprio.

$\S$ único - Nesse caso, o devedor somente estará obrigado a pagar mediante apresentação do título.

\section{Da Inscrição da Hipoteca}

Artigo ... - Todas as hipotecas serão inscritas no registro do lugar do imóvel, ou no de cada um deles, se o título se referir a mais de um.

Artigo ... - Para a inscrição das hipotecas haverá em cada cartório do registro de imóveis os livros necessários.

Artigo ... - As inscrições e averbações, nos livros de hipotecas, seguirão a ordem, em que forem requeridas, verificando-se ela pela da sua numeração sucessiva no protocolo.

$\S$ único - O número de ordem determina a prioridade, e esta a preferência entre as hipotecas.

Artigo ... - E' possível ao proprietário e ao credor, (na constituição da hipoteca,) no negócio de constituição de gravame, convencionarem que a hipoteca a ser inscrita posteriormente tenha prioridade de grau.

$\S 1^{\circ}$ - O negócio jurídico de reserva de grau deverá conter, pelo menos, o valor máximo do crédito a ser garantido e a data de seu vencimento.

$\S 2^{0}$ - A eficácia de direito real da aludida reserva de grau começa à data de sua averbação no registro de imóveis próprio e se transfere, com a alienação do bem, ao adquirente.

Artigo ... - E' permitido aos credores hipotecários ceder mutuamente os graus de prioridade, mas a eficácia real desses acordos supõe averbações no registro de imóveis.

Artigo ... - Quando o oficial tiver dúvida sobre a legalidade da inscrição requerida, declara-la-á por escrito ao requerente, depois de mencionar, em forma de prenotação, o pedido no respectivo livro.

Artigo ... - Se a dúvida, dentro em 90 dias, for julgada improcedente, a inscrição far-se-á com o mesmo número que teria na data da prenotação. No caso contrário, desprezada esta, receberá a inscrição o número correspondente à data, em que se tornar a requerer.

Artigo ... - Não se inscreverão no mesmo dia duas hipotecas, ou uma hipoteca e outro direito real, sobre o mesmo imóvel, em favor de pessoas diversas, salvo determinando-se precisamente a hora, em que se lavrou cada uma das escrituras.

Artigo ... - Compete aos interessados, exibindo o traslado da escritura, requerer a inscrição da hipo- 
teca; incumbindo especialmente promover a da legal às pessoas determinadas nos artigos seguintes.

Artigo ... - A inscrição da hipoteca, legal, ou convencional, declarará:

I - O nome, o domicílio e a profissão do credor e do devedor.

II - A data, a natureza do título, o valor do crédito e o da coisa ou sua estimação, fixada por acordo entre as partes, o prazo e os juros estipulados.

III - A situação, a denominação e os característicos da coisa hipotecada.

§ único - o credor, além do seu domicílio real, poderá designar outro, onde possa também ser citado.

Artigo ... - Os credores quirográficos e os por hipoteca não inscrita em primeiro lugar e sem concorrência, só por via de ação ordinária de nulidade ou rescisão poderão invalidar os efeitos da primeira hipoteca, a que compete a prioridade pelo respectivo registro.

\section{Das Modalidades da Hipoteca}

Artigo ... - A existência da hipoteca começa à data de sua inscrição.

Artigo ... - Pode-se convencionar uma hipoteca para garantir dívida futura ou condicionada.

Artigo ... - E' facultado constituir uma hipoteca determinado o valor máximo para o crédito a ser garantido.

$\S 1^{\circ}-$ A fixação efetiva do débito supõe a concordân cia posterior do devedor no documento da dívida, fazendo a mesma prova os livros comerciais.

$\S 2^{o}-A$ execução judicial, deve anteceder a averbação no registro do montante total da dívida.

Artigo ... - Ao proprietário, é permitido inscrever em seu favor uma hipoteca e extrair uma cédula, nos termos do disposto no artigo, endossável nominalmente.

\& único - Salvo disposição em sentido contrário, tal ônus real é totalmente autônomo da relação creditícia que porventura venha garantir.

\section{Das Hipotecas das Vias Férreas}

Artigo ... - As hipotecas sobre as estradas de ferro serão inscritas no município da estação inicial da respectiva linha.

Artigo ... - Os credores hipotecários não podem embaraçar a exploração da linha, nem contrariar as modificações, que a administração deliberar, no leito da estrada, em suas dependências, ou no seu material.

Artigo ... - A hipoteca será circunscrita à linha ou linhas especificadas na escritura e ao respectivo material de exploração, no estado em que ao tempo da execução estiverem. Não obstante, os credores hipotecários poderão opor-se à venda da estrada, à de suas linhas, de seus ramais, ou de parte considerável do material de exploração; bem como à fusão com outra empresa, sempre que a garantia do débito lhes parecer com isso enfraquecida.

Artigo ... - Nas execuções dessas hipotecas não se passará carta ao maior licitante, nem ao credor adjudicatório, antes de se intimar o representante da Fazenda Nacional, ou do Estado, a que tocar a preferência, para, dentro em quinze dias, utilizá-la, se quizer, pagando o preço da arrematação, ou da adjudicação fixada.

\section{Da Extinção da Hipoteca} poteca:

Artigo ... - São pressupostos para extinção da hi-

I - O desaparecimento da obrigação principal.

II - A destruição da coisa ou resolução do domínio.

III - A renúncia do credor.

IV - A remissão.

$\mathrm{V}$ - A sentença passada em julgado.

VI - A prescrição.

VII - A arrematação ou adjudicação.

Artigo ... - A hipoteca extingue-se com a averbação no respectivo registro.

Artigo ... - A inscrição cancelar-se-á, em cada um dos casos de extinção de hipoteca, à vista da respectiva prova ou, independente desta, a requerimento de ambas as partes, se forem capazes, e conhecidas do oficial de registro. 


\section{Do Registro de Imóveis}

Artigo ... - O registro de imóveis compreende:

I - A transcrição dos títulos de transmissão da propriedade.

II - A transcrição dos títulos enumerados no artigo 532.

III - A transcrição dos títulos constitutivos de ônus reais sobre coisas alheias.

IV - A inscrição das hipotecas.

Artigo ... - Se o título de transmissão for gratuito, poderá ser promovida a transcrição:

I - Pelo próprio adquirente.

II - Por quem de direito o represente.

III - Pelo próprio transferente, com prova da aceitação do beneficiado.

Artigo ... - A transcrição do título de transmissão do domínio direto aproveita ao titular do domínio útil, e vice-versa.

Artigo ... - Presume-se pertencer o direito real à pessoa, em cujo nome se inscreveu, ou transcreveu.

Artigo ... - Se o teor do registro de imóveis não exprimir a verdade, poderá o prejudicado reclamar que se retifique.

$\S$ único - Enquanto se não transcrever o título de transmissão, o alienante continua a ser havido como dono do imóvel, e responde pelos seus encargos.

Artigo ... - Serão feitas as inscrições, ou transcrições no registro correspondente ao lugar, onde estiver o imóvel.

Artigo ... - Salvo convenção em contrário, in cumbem ao adquirente as despesas da transcrição dos títulos de transmissão da propriedade e ao devedor as da inscrição, ou transcrição dos ônus reais.

\section{Da Anticrese}

Artigo ... - Pode o devedor, ou outrem por ele, entregando ao credor um imóvel, um patrimônio inteiro, ou parte deste, ceder-lhe o direito de perceber, em compensação da divida, os frutos e rendimentos.
$\S 1^{\circ}$ - permitido estipular que os frutos e rendimentos do imóvel, ou do patrimônio, sejam percebidos pelo credor à conta de juros, mas se o seu valor ultrapassar a taxa máxima permitida em lei e a da desvalorização da moeda, o remanescente será imputado ao capital.

$\S 2^{\circ}-$ Quando a anticrese recair sobre bens imóveis, estes podem ser dados pelo devedor em hipoteca ao credor anticrético, ou a terceiros, assim como o imóvel hipotecado pode ser também dado em anticrese.

Artigo ... - O credor anticrético poderá administrar os bens dados em anticrese e fruir seus frutos e utilidades, mas deverá apresentar anualmente um balanço, exato e fiel, de sua administração.

$\& 1^{\circ}$ - Se o devedor anticrético não concordar com o que se contém no balanco, por ser inexato, ou ruinosa a administração, poderá impugná-lo e, se o preferir, requerer a transformação em arrendamento, fixando o juiz o valor mensal do aluguel, o qual poderá ser corrigido anualmente.

$\S 2^{\circ}$ - $\mathrm{O}$ credor anticrético pode, salvo pacto em sentido contrário, arrendar os bens dados em anticrese a terceiro (mantendo, nesse caso, até ser pago o direito de retenção do imóvel), embora o aluguel desse arrendamento não seja vinculativo para o devedor.

Artigo ... - $\mathrm{O}$ credor anticrético responde pelas deteriorações que, por culpa sua, o imóvel ou o patrimônio vier a sofrer e pelos frutos e rendimentos, que, por sua negligência, deixar de receber.

Artigo .... - $\mathrm{O}$ credor anticrético pode vindicar os seus direitos contra o adquirente dos bens, os credores quirografários e os hipotecários posteriores à transcrição da anticrese.

$\S 1^{\circ}$ - Se, porém, executar os bens por não pagamento da dívida, ou permitir que outro credor o execute, sem opor o seu direito de retenção ao exequente, não terá preferência sobre o preço.

$\S 2^{\mathrm{C}}$-- Também não terá sobre a indenização do seguro, quando o prédio seja destruído, nem se forem desapropriados os bens, sobre a desapropriação.

Artigo ... - Antes do vencimento da dívida, prestando a ssua totalidade da dívida à data do pedido de remição, imitindo-se, se for o caso, na sua posse. 